\title{
Kidney, Splanchnic, and Leg Protein Turnover in Humans Insight from Leucine and Phenylalanine Kinetics
}

\author{
Paolo Tessari, Giacomo Garibotto, ${ }^{\star}$ Sandro Inchiostro, Cristina Robaudo, ${ }^{\star}$ Stefano Saffioti, ${ }^{*}$ Monica Vettore, Michela Zanetti, \\ Rodolfo Russo, ${ }^{\star}$ and Giacomo Deferrari* \\ Department of Metabolic Diseases, University of Padova; and *Division of Nephrology, Department of Internal Medicine,
} University of Genova, Italy

\begin{abstract}
The rate of kidney protein turnover in humans is not known. To this aim, we have measured kidney protein synthesis and degradation in postabsorptive humans using the arterio-venous catheterization technique combined with ${ }^{14} \mathrm{C}$-leucine, ${ }^{15} \mathrm{~N}$-leucine, and ${ }^{3} \mathrm{H}$-phenylalanine tracer infusions. These measurements were compared with those obtained across the splanchnic bed, the legs $(\approx$ muscle) and in the whole body. In the kidneys, protein balance was negative, as the rate of leucine release from protein degradation $\left(16.8 \pm 5.1 \mu \mathrm{mol} / \mathrm{min} \cdot 1.73 \mathrm{~m}^{2}\right)$ was greater $(P<0.02)$ than its uptake into protein synthesis $(11.6 \pm 5.1 \mu \mathrm{mol} / \mathrm{min} \cdot 1.73$ $\mathrm{m}^{2}$ ). Splanchnic net protein balance was $\approx 0$ since leucine from protein degradation $\left(32.1 \pm 9.9 \mu \mathrm{mol} / \mathrm{min} \cdot 1.73 \mathrm{~m}^{2}\right)$ and leucine into protein synthesis $(30.8 \pm 11.5 \mu \mathrm{mol} / \mathrm{min} \cdot 1.73$ $\mathrm{m}^{2}$ ) were not different. In the legs, degradation exceeded synthesis $\left(27.4 \pm 6.6\right.$ vs. $20.3 \pm 6.5 \mu \mathrm{mol} / \mathrm{min} \cdot 1.73 \mathrm{~m}^{2}, P<$ $0.02)$. The kidneys extracted $\alpha$-ketoisocaproic acid, accounting for $\approx 70 \%$ of net splanchnic $\alpha$-ketoisocaproic acid release. The contributions by the kidneys to whole-body leucine rate of appearance, utilization for protein synthesis, and oxidation were $\approx 11 \%, \approx 10 \%$, and $\approx 26 \%$, respectively; those by the splanchnic area $\approx 22 \%, \approx 27 \%$, and $\approx 18 \%$; those from estimated total skeletal muscle $\approx 37 \%, \approx 34 \%$, and $\approx 48 \%$. Estimated fractional protein synthetic rates were $\approx 42 \% / \mathrm{d}$ in the kidneys, $\approx 12 \%$ in the splanchnic area, and $\approx 1.5 \%$ in muscle. This study reports the first estimates of kidney protein synthesis and degradation in humans, also in comparison with those measured in the splanchnic area, the legs, and the whole-body. (J. Clin. Invest. 1996. 98:14811492.) Key words: kidney • splanchnic bed $\bullet$ muscle • organ catheterization • leucine kinetics
\end{abstract}

\section{Introduction}

Body proteins turn over at different rates, therefore their individual contribution to whole-body amino acid kinetics is quan-

Address correspondence to Prof. Paolo Tessari, M.D., Cattedra di Malattie del Ricambio, Dept. of Medicina Clinica, via Giustiniani 2, 35128 Padova, Italy. FAX: 39-49-8754179.

Received for publication 9 February 1996 and accepted in revised form 10 July 1996.

J. Clin. Invest.

(C) The American Society for Clinical Investigation, Inc.

0021-9738/96/09/1481/12 \$2.00

Volume 98, Number 6, September 1996, 1481-1492 titatively and qualitatively heterogeneous (1). Whole-body turnover studies, by definition, do not allow to quantitate protein and/or amino acid metabolism in individual organs and/or tissues. These data can be obtained only by using organ catheterization and/or tissue biopsy during amino acid isotope infusions. Knowledge of rates of regional protein turnover in humans is important not only from a physiological standpoint, but also for the investigation of the site(s) and the mechanism(s) of altered protein turnover in disease.

Most in vivo regional studies of protein turnover have been focused on skeletal muscle, which is the main deposit of body proteins $(2,3)$. Besides muscle, however, the kidneys and splanchnic organs may also play an important role in body protein homeostasis $(1,4)$. It is well known from in vitro studies that renal tissues have a high fractional protein turnover rate $(5,6)$, therefore they might contribute to whole-body protein synthesis and degradation more than what would be expected from their small mass. Furthermore, it is necessary to know the physiological rates of renal protein synthesis and degradation to learn to which extent and by which mechanisms changes of renal mass occur in pathological states such as compensatory hypertrophy (7) or diabetes (8). To date, no in vivo estimates of kidney protein synthesis and degradation are available either in animals or in humans. Furthermore, although the kidneys may selectively take up or release individual amino acids $(9,10)$, no study has ever specifically addressed this issue from a kinetic standpoint.

Also, splanchnic organs may play a crucial role in the regulation of body protein turnover, because of their mass, their specific protein turnover rates, and their anatomical location $(1,4)$. In one human study $(11)$, fractional protein synthetic rates in liver and in the colonic mucosa, calculated through the biopsy technique, were reported to be relatively high $(\approx 20-$ $25 \% / \mathrm{d}$ in the liver; $\approx 9 \% / \mathrm{d}$ in colon). In that study, however, protein degradation was not simultaneously measured. Rates of amino acid uptake (i.e., total disposal) and release (i.e., proteolysis) across the splanchnic bed were also measured by combining the arterio-hepatic vein catheterization technique with phenylalanine and/or leucine isotope infusion in normal subjects $(12,13)$. However, since these two essential amino acids are also degraded by splanchnic tissues (14-16), their uptake couldn't be equated to protein synthesis. More recently, the splanchnic catheterization approach was combined with isotope infusions to estimate splanchnic protein synthesis and degradation in insulin-deprived and insulin-infused type 1 diabetics (17). Splanchnic protein synthesis was greater during insulin deficiency than during insulin infusion (17). Although the insulin-infused insulin-dependent diabetes mellitus patients may behave as metabolically normal; as a matter of fact no data are yet available on splanchnic protein synthesis, degradation, and net balance measured simultaneously in normal humans. 
Therefore, this study was undertaken to measure amino acid (and protein) turnover across the kidneys, the splanchnic area, and the legs, in metabolically normal postabsorptive humans. The studies were performed by using the arterio-venous $(\mathrm{A}-\mathrm{V})^{1}$ catheterization technique combined with infusions of leucine and phenylalanine tracers. Leucine kinetics was investigated comprehensively, since we measured also its oxidation by means of ${ }^{14} \mathrm{C}$-bicarbonate production across the sampled organs, as well as the metabolism of its deamination product, $\alpha$-ketoisocaproic acid (KIC).

\section{Methods}

\section{Subjects}

10 subjects ( 5 men and 5 women, age $37 \pm 4$ yr, range $21-50 \mathrm{yr}$ ) were studied in the postabsorptive state. All were within $110 \%$ of their ideal body weight based on Metropolitan Life Insurance tables (18). Starting from at least 1 mo before admission, they were on a diet which provided $30-35 \mathrm{kcal} / \mathrm{d}$ and $0.9-1$ grams of protein $/ \mathrm{kg}$ of body weight, as assessed by dietary history and urea excretion. Routine laboratory tests, glomerular filtration rate, acid-base balance, electrolyte measurements, and oral glucose tolerance tests were normal. No subject had either history or clinical evidence of gastrointestinal or hepatic disease, congestive heart failure, kidney disease, diabetes mellitus, or other endocrinopathies.

Five subjects (three men, two women) had arterial hypertension. Their mean blood pressure ranged between 125 and $135 \mathrm{mmHg}$. A renal vein catheterization for renin activity was considered helpful for diagnostic purposes. The final diagnosis was benign arterial hypertension. The remaining five subjects had cardiac valvular disease, and a right-sided cardiac catheterization was considered necessary for diagnostic hemodynamic evaluation.

According to the diagnostic procedure per se, which is performed through a femoral approach, all patients underwent a femoral vein catheterization. All hypertensive subjects underwent the renal vein catheterization study, and three of them also underwent that of the hepatic vein. Conversely, all subjects with valvular heart disease underwent the hepatic vein study, and two of them also underwent that of the renal vein. Thus, the number of subjects who underwent the leg, the renal, and the hepatic vein catheterization study was 10,7 , and 8 , respectively.

All subjects were informed about nature, purposes, procedure, and possible risks of the study before their voluntary consent was obtained. The study was part of a larger protocol approved by the Ethical Committee of the Department of Internal Medicine, at the University Hospital of Genova. The procedures were in accordance with the Helsinki Declaration.

\section{Isotopes}

L- $\left[1-{ }^{14} \mathrm{C}\right]$ Leucine $(55 \mathrm{mCi} / \mathrm{mmol})\left({ }^{14} \mathrm{C}\right.$-Leu $),{ }^{14} \mathrm{C}$-sodium bicarbonate $(100 \mathrm{mCi} / \mathrm{mmol})$, and $\mathrm{L}-\left[2,6-{ }^{3} \mathrm{H}\right]$ phenylalanine $\left({ }^{3} \mathrm{H}-\mathrm{Phe}\right)$ were purchased from DuPont-NEN (European Division, Brussels, Belgium). $\mathrm{L}-\left[{ }^{15} \mathrm{~N}\right]$ Leucine $\left({ }^{15} \mathrm{~N}-\mathrm{Leu}\right)$ was purchased from Tracer Technologies (Somerville, MA). All the stable isotope were $>99 \%$ mole percent enriched. All isotopes were proven to be sterile and pyrogen-free before use.

\section{Procedures}

The patients were studied in the recumbent position in the postabsorptive state. At about 08:00 a.m., a peripheral vein was cannulated with a Teflon catheter and used for isotope infusions. A preinfusion

1. Abbreviations used in this paper: $\mathrm{A}-\mathrm{V}$, arterio-venous; $\mathrm{KIC}, \alpha-$ ketoisocaproic acid; MPE, mole percent enrichment; PCA, perchloric acid; SA, specific activity. sample was collected to measure basal isotope enrichments. Thereafter, primed-constant isotope infusions were started by means of calibrated pumps. The constant isotope infusion rates were the following: ${ }^{14} \mathrm{C}-$ Leu $=6,298 \pm 748 \mathrm{dpm} / \mathrm{kg} \cdot \mathrm{min} ;{ }^{3} \mathrm{H}-\mathrm{Phe}=8,578 \pm 479 \mathrm{dpm} /$ $\mathrm{kg} \cdot \min ;{ }^{15} \mathrm{~N}-\mathrm{Leu}=0.32 \pm 0.04 \mu \mathrm{mol} / \mathrm{kg} \cdot \mathrm{min}$. Priming doses of all tracers (in the amount equivalent to $\approx 30$ times the continuous infusion rates per minute), as well as a priming dose of ${ }^{14} \mathrm{C}$-bicarbonate $(\approx 3$ $\mu \mathrm{Ci}$ ), were administered at time 0 .

After $120 \mathrm{~min}$, the procedures for catheter positioning were started. A Teflon catheter was inserted percutaneously into a radial artery. Two introducer sets $(8.5 \mathrm{~F}), 1 \mathrm{~cm}$ away from each other, were placed into the femoral vein. A Cobra 7F catheter (William Cook Europe, Bjaeverskov, Denmark) was then guided under fluoroscopic control through a femoral vein, either to the right ventricular cavity or to a renal vein. Short Teflon sheaths, surrounding the catheters from their insertion sites to a level just above the inguinal ligament, allowed simultaneous sampling of femoral blood flow. After the diagnostic procedure was completed, another catheter was introduced to allow simultaneous sampling from the renal and the hepatic veins. The position of the catheters was ascertained visually through image intensification before starting blood withdrawal. The total exposure due to the radioactive isotopes was estimated to be $<100 \mathrm{mrad}(19)$. The total radiation dose absorbed from fluoroscopy was estimated to $\mathrm{be} \approx 20-30 \mathrm{mrad}$. Such an estimate resulted from the characteristic of the instrumentation (which provided an absorbed dose of $\approx 120-130$ $\operatorname{mrad}$ per $\mathrm{h}^{-1}$ ) and the time used to position the venous catheter(s) (about $5 \mathrm{~min}$ for each site). Also, it should be considered that the absorbed radiation involved the draining vein rather than the organ itself. The catheters were kept patent by flushing with saline intermittently. Blood samples were effectively taken after $\approx 210 \mathrm{~min}$ from the start of isotope infusion. Three sets of blood samples were obtained at $\sim 20$-min intervals from the radial artery as well as the renal, hepatic, and femoral veins for the biochemical analyses. Each set of samples was drawn almost simultaneously from the different vessels. Substrate and isotope concentrations, specific activities (SA) enrichments, and expired ${ }^{14} \mathrm{CO}_{2}$ were at steady state by this time (data not reported). Achievement of steady state after primed-continuous isotope infusions of either comparable or shorter duration also has been reported in many published amino acid turnover studies (for reviews see references 20 and 21). Blood samples were withdrawn into heparinized syringes kept in ice. At the same time points, additional samples were taken for measurements of organ blood flow, as described below. Urine flow was collected via a bladder catheter. Therefore, the total duration of the study was $\sim 4 \mathrm{~h}$.

Arterial blood pressure and electrocardiogram were continuously monitored during the study. Room temperature was maintained between 20 and $22^{\circ} \mathrm{C}$.

\section{Analytical measurements}

Two sets of blood samples ( $2 \mathrm{ml}$ each) were collected into tubes containing $2 \mathrm{ml}$ of $20 \%$ perchloric acid (PCA). The amounts of blood as well as of PCA were accurately measured with calibrated pipettes to allow a precise measurement of blood dilution. The tubes were immediately and vigorously shaken. After centrifugation at $4^{\circ} \mathrm{C}$, the supernatant was stored at $-20^{\circ} \mathrm{C}$ until assay. SA of leucine (22), phenylalanine (23), and KIC (22), as well as KIC concentration (22), were determined by applying the referenced HPLC plasma methods to whole-blood. Blood KIC concentration was calculated by multiplying the HPLC value by two, in order to correct for PCA dilution of blood (as outlined above). Whole-blood leucine, phenylalanine, and other amino acid concentrations were measured with ion exchange chromatography by using an amino acid analyzer (Fisons Instruments Italia SPA, Milan, Italy) (9) and lithium buffers. We found a tight correlation (data here not reported) between values of leucine and phenylalanine concentrations measured by the two methods (i.e., the wholeblood HPLC assay and the ion exchange chromatography). The latter data were used for calculations. ${ }^{15} \mathrm{~N}$-Leu mole percent enrichment (MPE) was determined in the supernatant of deproteinized blood by 
gas chromatography mass spectrometry as tert-butyl-dimethyl-silyl derivative and electron impact ionization (24), by monitoring the fragments [m/z] 201/200. Enrichment was expressed as tracer/tracer + tracee ratio. Blood isotope concentrations were calculated by multiplying SA or MPE times unlabeled substrate concentrations. In one subject, no measurements of KIC concentrations, KIC SA, ${ }^{15} \mathrm{~N}-\mathrm{leu}-$ cine enrichment, and ${ }^{14} \mathrm{C}$-bicarbonate concentrations (see below) were available. Arterial and deep venous blood concentrations of ${ }^{14} \mathrm{C}$-bicarbonate were measured as described (25). Arterial plasma insulin (26) and glucagon (27) concentrations were determined by radioimmunoassay as indicated.

\section{Organ blood flow measurements}

Hepatic blood flow was estimated by the continuous infusion technique (28) using indocyanine green dye (Becton Dickinson, Cockeysville, MD). Renal plasma flow was measured by the clearance of exogenously infused PAH (9). Three sequential clearance periods of 20 min each were obtained. Renal arterial plasma flow was calculated from the clearance and extraction of PAH using Wolf's equation (29). True renal arterial blood flow was calculated by dividing plasma flow over [ 1 - hematocrit].

Leg blood flow was estimated from the arterial-venous difference of oxygen and $\mathrm{VO}_{2}(30,31)$. By this technique, blood flow data are expressed per two legs.

\section{Calculations and data presentation}

All kinetic data were expressed in $\mu \mathrm{mol} / \mathrm{min} \cdot 1.73 \mathrm{~m}^{2}$, i.e., they were normalized as if each patient's body surface was the same (i.e., $1.73 \mathrm{~m}^{2}$ ).

There are several theoretical possibilities to calculate amino acid kinetics across organs. In this study, we have used three different models to calculate organ leucine kinetics: (1) a six-compartment model of leucine and KIC, recently described (25); (2) the forearm model described by Cheng et al. (32); and (3) a noncompartmental model of leucine and $\mathrm{KIC}$, based on organ extractions of combined ${ }^{14} \mathrm{C}$-leucine and ${ }^{14} \mathrm{C}$-KIC, as well as on venous KIC SA as intracellular precursor pool. Organ phenylalanine kinetics was calculated using the A-V model described by Barrett and Gelfand (3).

Compartmental leucine and KIC model. This model is based on a physiologic organ compartmentation of leucine and KIC. For each compound, three compartments, one arterial, one intracellular, and one venous, are assumed (25). Model equations have been presented and discussed in detail elsewhere (25). Briefly, the model assumptions are here summarized. (a) The SA of ${ }^{14} \mathrm{C}$-KIC, measured in the venous blood draining the sampled organ (i.e., the femoral, the hepatic, and the renal vein) is taken as representative of intracellular ${ }^{14} \mathrm{C}$-leucine as well as ${ }^{14} \mathrm{C}$-KIC SA of that organ. This assumption is based on recent animal and human studies (33-39) in which venous KIC SA or enrichment were compared with the leucine SA or enrichment directly measured either in the intracellular space (33-37) or in the leucyl-tRNA, i.e., the precursor of protein synthesis $(34,35)$, or incorporated into a fast turning over, liver-synthesized protein such as VLDL apoB-100 at steady state $(38,39)$. (b) The ${ }^{15} \mathrm{~N}$-leucine tracer extracted by each organ is used to calculate leucine inward ([F2] model parameter) and outward [F3] movement across the cell membrane, as well as leucine and KIC interconversion rates ([F7 and F8], respectively) (25). Conversely, the fraction of ${ }^{15} \mathrm{~N}$-leucine tracer not taken up by the forearm is used to calculate the leucine which bypasses intracellular metabolism and is released directly into the vein [F12]. (c) A single, well-mixed intracellular leucine pool is also assumed, from and into which all entries and exits take place. The same assumptions are made in regard to a homogeneous intracellular KIC pool. (d) No interstitial leucine and KIC compartment is considered. In other words, the ${ }^{14} \mathrm{C}$-leucine, the ${ }^{14} \mathrm{C}-\mathrm{KIC}$, and the ${ }^{15} \mathrm{~N}$-leucine isotopes are assumed to enter their corresponding intracellular compartments at the arterial values. Conversely, they are assumed to be released from their intracellular compartments at the measured deep venous values. (e) No release of tracer(s) recycled from protein breakdown into the intracellular leucine compartment is assumed to occur within the duration of study. $(f)$ There is no inde- pendent production of KIC inside the cell except that deriving from either leucine or blood. ( $g$ ) Finally, we assumed that the metabolic behavior of the ${ }^{14} \mathrm{C}$-tracer(s) is the same as that of unlabeled material.

Cheng's $A$-V model (32). The original model has been adapted to the use of radioactive ${ }^{14} \mathrm{C}$-leucine isotope. Moreover, since we did not infuse a di-labeled ${ }^{13} \mathrm{C}$-, ${ }^{15} \mathrm{~N}$-leucine (32), but a mono-labeled ${ }^{15} \mathrm{~N}$ leucine, the enrichment of this latter tracer was used instead. The modified equations are reported here:

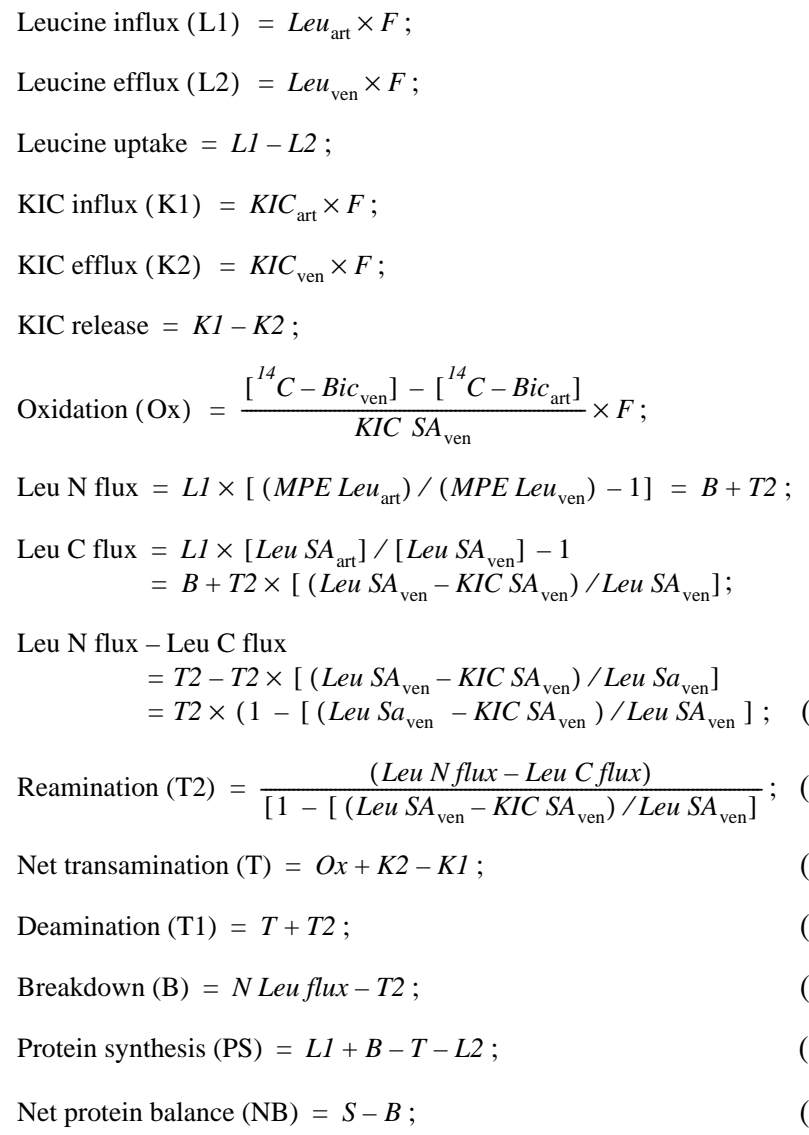

where $\mathrm{Leu}_{\text {art }}$ and $\mathrm{Leu}_{\mathrm{ven}}$ are the concentrations $(\mathrm{nmol} / \mathrm{ml})$ of leucine in artery and vein, respectively; $\mathrm{F}$ is blood flow; $\mathrm{KIC}_{\mathrm{art}}$ and $\mathrm{KIC}_{\mathrm{ven}}$ are $\mathrm{KIC}$ concentrations $(\mathrm{nmol} / \mathrm{ml})$ in artery and vein, respectively; SA is given in dpm/nmol; MPE indicates ${ }^{15} \mathrm{~N}$-leucine MPE; $\left[{ }^{14} \mathrm{C}-\mathrm{Bic}_{\mathrm{ven}}\right]$ and $\left[{ }^{14} \mathrm{C}-\mathrm{Bic}_{\mathrm{art}}\right]$ are ${ }^{14} \mathrm{C}$-bicarbonate concentrations $(\mathrm{dpm} / \mathrm{ml})$ in artery and vein, respectively; Leu $\mathrm{N}$ and Leu $\mathrm{C}$ flux indicate leucine flux calculated with ${ }^{15} \mathrm{~N}$-leucine and with ${ }^{14} \mathrm{C}$-leucine tracers, respectively.

All data were expressed in $\mu \mathrm{mol} / \mathrm{min} \cdot 1.73 \mathrm{~m}^{2}$.

Noncompartmental model of leucine and KIC. This model represents a simplification of the six-compartment model described above. No compartmentation of leucine and KIC is assumed, but both the leucine and the KIC species are considered together in the calculation of total leucine-carbon uptake and release across organs. In analogy to the compartmental model, venous KIC SA is considered as the precursor pool to calculate all intracellular kinetic rates.

Thus, the rate of disappearance across the organ of total leucinecarbon (Leu-C) (i.e., leucine plus KIC) is calculated from the sum of ${ }^{14} \mathrm{C}$-leucine and ${ }^{14} \mathrm{C}$-KIC net extraction, divided by venous KIC SA

Leu-C Rd $=\frac{*[L e u+K I C]_{\mathrm{art}}-*[L e u+K I C]_{\mathrm{ven}}}{K I C S A_{\mathrm{ven}}} \times F$

where $*[\mathrm{Leu}+\mathrm{KIC}]$ is the sum of concentrations $(\mathrm{dpm} / \mathrm{ml})$ of radioactive leucine and KIC in the arterial (art) or venous (ven) blood, re-

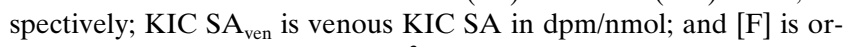
gan blood flow (in $\mathrm{ml} / \mathrm{min} \cdot 1.73 \mathrm{~m}^{2}$ ). 
Net leucine-carbon balance (NB) was calculated as the [arterial venous] difference of leucine + KIC concentration [Leu + KIC] (expressed in $\mathrm{nmol} / \mathrm{ml}$ ), multiplied by flow:

Leu-C NB $=\left([L e u+K I C]_{\mathrm{art}}+-[\mathrm{Leu}+\mathrm{KIC}]_{\mathrm{ven}}\right) \times F$,

Organ leucine-carbon rate of appearance $\left(R_{\mathrm{a}}\right)$ was calculated by subtracting net balance from $R_{\mathrm{d}}$ :

Leu-C $R_{\mathrm{a}}=$ Leu-C $R_{\mathrm{d}}-$ Leu-C NB .

Leucine-carbon oxidation was calculated in the same fashion as the other models, i.e., by dividing the [venous - arterial] difference of ${ }^{14} \mathrm{C}$-bicarbonate concentration $\left({ }^{14} \mathrm{C}\right.$-Bic) (in $\mathrm{dpm} / \mathrm{ml}$ ) over venous KIC SA, and multiplying it by blood flow:

Leu-C Ox $=\frac{\left[{ }^{14} C-B i c_{\text {ven }}\right]-\left[{ }^{14} C-B i c_{\text {art }}\right]}{K I C S A_{\text {ven }}} \times F$.

The rate of leucine-carbon utilization for organ protein synthesis (Leu-C $\rightarrow$ PS) was then calculated by subtracting Leu-C oxidation from Leu-C $R_{\mathrm{d}}$ :

Leu-C $\rightarrow$ Ox $=\left[\right.$ Leu-C $\left.R_{\mathrm{d}}\right]-[$ Leu-C Ox $]$.

Fractional amino acid extraction was calculated by dividing the amino acid venous-arterial concentration difference by its arterial concentration:

Fractional extraction $=\frac{\left[A A_{\mathrm{ven}}\right]-\left[A A_{\mathrm{art}}\right]}{\left[A A_{\mathrm{art}}\right]} \times 100$.

Fractional extraction is based only on unlabeled amino acid data. To estimate the fraction of arterial amino acid delivery to organ which is taken up as $R_{\mathrm{d}}$, we have calculated also fractional amino acid (AA) uptake as follows:

Fractional AA uptake $=\frac{A A R_{\mathrm{d}}}{\left[A A_{\text {art }}\right] * F} \times 100$.
Splanchnic amino acid kinetics is the reflection of both liver and gut metabolism. However, without sampling in the portal vein, the individual contributions by these districts cannot be calculated. Therefore, the kinetic data reflected the splanchnic area as a whole.

As outlined above, leg blood flow and therefore the leg kinetic data were referred to the two legs together. To extrapolate the data to whole body skeletal muscle, the data of two legs were multiplied by two $(2,12,30)$.

Leg amino acid metabolism may include also that of skin and bone. However, at least from animal studies, skin may contribute by no more than $10 \%$ to leg protein turnover $(40)$. Leg bone protein turnover has never been determined in vivo, at least to our knowledge, therefore it was assumed to be $\approx 0$.

In regard to the kidneys, since blood flow included the two kidneys together, the amino acid kinetic data also refer to the combined two kidneys.

Whole-body calculations. Whole-body amino acid kinetics was calculated using conventional calculations, i.e., both primary and reciprocal pool models for leucine (41), as well as a primary pool model for phenylalanine (20). A fixed whole-body fixation factor for ${ }^{14} \mathrm{CO}_{2}$ of $20 \%$ was used (42). No fixation factor of ${ }^{14} \mathrm{C}$-bicarbonate across organs was used, since in the only study in which this issue was investigated (43), no apparent ${ }^{14} \mathrm{C}$-bicarbonate extraction was observed.

The statistical analysis was performed using two-tailed paired tests (either the Student $t$ test when data distribution was normal, or the Wilcoxon test when it was not normal) to compare, within the same individuals, the arterial to the venous data, as well as two sets of organ kinetic parameters (for instance: protein degradation [F5] vs. synthesis [F6]; leucine deamination [F7] vs. reamination [F8]; leucine inflow [F2] vs. outflow [F3] into/from cell). One-way ANOVA and the Neumann-Keul's test were used to compare three groups of data. All data were expressed as means \pm SE. A $P$ value $<0.05$ was considered as statistically significant.

\section{Results}

Substrate and isotope concentrations, $S A$ and blood flow

Kidneys. Blood flow in the kidneys was $946 \pm 80 \mathrm{ml} / \mathrm{min} \cdot 1.73$

Table I. Whole-Blood Leu, KIC and Phe Concentrations (nmol/ml), ${ }^{14} \mathrm{C}-\mathrm{Leu},{ }^{14} \mathrm{C}-\mathrm{KIC}$, and ${ }^{3} \mathrm{H}$-Phe Isotope Concentrations (dpm/ $\mathrm{ml})$ and $\mathrm{SA}(\mathrm{dpm} / \mathrm{nmol}),{ }^{15} \mathrm{~N}$-Leu Concentration (nmol/ml), and MPE, and ${ }^{14} \mathrm{C}$-bicarbonate Concentrations $($ dpm/ml)

\begin{tabular}{|c|c|c|c|c|c|c|}
\hline & \multicolumn{2}{|c|}{ Kidneys } & \multicolumn{2}{|c|}{ Splanchnic bed } & \multicolumn{2}{|c|}{ Legs } \\
\hline & Artery & Renal vein & Artery & Hepatic vein & Artery & Femoral vein \\
\hline \multicolumn{7}{|c|}{ Substrate concentrations } \\
\hline Leu & $133.8 \pm 9.1$ & $136.1 \pm 9.6^{*}$ & $139.3 \pm 12.2$ & $132.9 \pm 10.9^{*}$ & $136.9 \pm 9.7$ & $140.9 \pm 10.5^{\ddagger}$ \\
\hline $\mathrm{KIC}$ & $29.3 \pm 1.7$ & $26.1 \pm 0.8^{\ddagger}$ & $30.5 \pm 2.1$ & $34.0 \pm 2.4^{\ddagger}$ & $29.2 \pm 1.6$ & $28.5 \pm 1.1$ \\
\hline Phe & $39.9 \pm 3.6$ & $36.3 \pm 2.3^{\ddagger}$ & $38.3 \pm 3.6$ & $33.4 \pm 3.1^{\ddagger}$ & $37.6 \pm 2.8$ & $42.7 \pm 3.1^{\ddagger}$ \\
\hline \multicolumn{7}{|c|}{ Isotope concentrations } \\
\hline${ }^{14} \mathrm{C}$-Leu & $341 \pm 53$ & $305 \pm 43^{\ddagger}$ & $433 \pm 42$ & $338 \pm 33^{\ddagger}$ & $390 \pm 45$ & $332 \pm 40^{\ddagger}$ \\
\hline${ }^{14} \mathrm{C}-\mathrm{KIC}$ & $70 \pm 12$ & $57 \pm 9$ & $86 \pm 8$ & $103 \pm 14 *$ & $74 \pm 9$ & $71 \pm 10$ \\
\hline${ }^{3} \mathrm{H}-\mathrm{Phe}$ & $389 \pm 69$ & $302 \pm 49^{\ddagger}$ & $378 \pm 66$ & $233 \pm 42^{\ddagger}$ & $360 \pm 55$ & $298 \pm 50$ \\
\hline${ }^{15} \mathrm{~N}-\mathrm{Leu}$ & $11.6 \pm 2.3$ & $10.8 \pm 2.1^{*}$ & $12.6 \pm 2.3$ & $7.9 \pm 1.4^{\ddagger}$ & $12.9 \pm 1.8$ & $8.4 \pm 1.3^{\ddagger}$ \\
\hline${ }^{14} \mathrm{C}-\mathrm{Bic}$ & $117 \pm 18$ & $131 \pm 20^{\S}$ & $151 \pm 19$ & $161 \pm 20^{\S}$ & $133 \pm 18$ & $147 \pm 22^{\S}$ \\
\hline \multicolumn{7}{|l|}{ SA and MPE } \\
\hline${ }^{14}$ C-Leu SA & $2.54 \pm 0.34$ & $2.26 \pm 0.3^{\ddagger}$ & $3.31 \pm 0.51$ & $2.68 \pm 0.38^{\ddagger}$ & $12.98 \pm 0.46$ & $2.48 \pm 0.39^{\ddagger}$ \\
\hline${ }^{14} \mathrm{C}-\mathrm{KIC}$ SA & $2.37 \pm 0.4$ & $2.17 \pm 0.35^{\ddagger}$ & $2.87 \pm 0.28$ & $3.03 \pm 0.33$ & $2.54 \pm 0.31$ & $2.51 \pm 0.36$ \\
\hline${ }^{3} \mathrm{H}-\mathrm{Phe} \mathrm{SA}$ & $9.54 \pm 1.19$ & $8.33 \pm 1.22^{\ddagger}$ & $9.56 \pm 1.14$ & $6.76 \pm 0.74^{\ddagger}$ & $9.18 \pm 0.94$ & $6.69 \pm 0.83^{\ddagger}$ \\
\hline${ }^{15} \mathrm{~N}-$ Leu MPE & $8.94 \pm 1.72$ & $8.24 \pm 1.66^{\ddagger}$ & $9.29 \pm 1.57$ & $6.87 \pm 1.06^{\ddagger}$ & $9.71 \pm 1.25$ & $6.16 \pm 0.82$ \\
\hline
\end{tabular}

Arterial values are reported separately, because renal and hepatic veins were not sampled in all subjects. ${ }^{*} P<0.05 ;{ }^{\S} P<0.03$; ${ }^{\ddagger} P<0.01$ vs. the corresponding artery. 
Table II. Blood Arterial Amino Acid Concentrations (Conc art) and Net Balance ([A-V]) ( $\mu m o l / l i t e r)$

\begin{tabular}{|c|c|c|c|c|c|c|}
\hline & \multicolumn{2}{|c|}{ Kidneys } & \multicolumn{2}{|c|}{ Splanchnic bed } & \multicolumn{2}{|c|}{ Legs } \\
\hline & Conc $_{\text {art }}$ & {$[\mathrm{A}-\mathrm{V}]$} & Conc $_{\text {art }}$ & {$[\mathrm{A}-\mathrm{V}]$} & Conc $_{\text {art }}$ & {$[\mathrm{A}-\mathrm{V}]$} \\
\hline Taurine & $244 \pm 12$ & $+3.3 \pm 2.2$ & $218 \pm 28$ & $-4.1 \pm 4.5$ & $223 \pm 20$ & $-4.5 \pm 3.2$ \\
\hline Threonine & $92 \pm 9$ & $-4 \pm 0.4^{*}$ & $106 \pm 4$ & $+17 \pm 5.1^{\ddagger}$ & $98 \pm 7$ & $-11.9 \pm 2.6^{\ddagger}$ \\
\hline Serine & $98 \pm 4$ & $-20.6 \pm 4.2^{*}$ & $100 \pm 7$ & $+13.8 \pm 5.2^{\ddagger}$ & $103 \pm 4$ & $-2.7 \pm 1.1^{\ddagger}$ \\
\hline Glycine & $226 \pm 15$ & $+5.4 \pm 3.2$ & $226 \pm 11$ & $+15.5 \pm 7.6$ & $217 \pm 12$ & $-14.7 \pm 2.7^{*}$ \\
\hline Alanine & $237 \pm 11$ & $-6.8 \pm 3.3^{\ddagger}$ & $237 \pm 27$ & $+110 \pm 29.8^{\S}$ & $236 \pm 21$ & $-44.7 \pm 8.2 *$ \\
\hline Citrulline & $28 \pm 3$ & $+3.8 \pm 1.1^{\ddagger}$ & $22 \pm 3$ & $-6.4 \pm 1^{\S}$ & $24 \pm 3$ & $-1 \pm 0.8$ \\
\hline Valine & $155 \pm 9$ & $-3.7 \pm 2$ & $157 \pm 13$ & $+8.5 \pm 0.8^{*}$ & $157 \pm 11$ & $-6 \pm 1.5^{\S}$ \\
\hline Cyst(e)ine & $33 \pm 6$ & $-6.8 \pm 1.4^{\S}$ & $38 \pm 5$ & $+3.2 \pm 1.5^{\ddagger}$ & $37 \pm 4$ & $+2 \pm 0.7^{\ddagger}$ \\
\hline Isoleucine & $31 \pm 5$ & $-1.1 \pm 1.2$ & $29 \pm 5$ & $+0.8 \pm 1.4$ & $31 \pm 4$ & $-2.9 \pm 0.7^{\S}$ \\
\hline Tyrosine & $41 \pm 4$ & $-3.5 \pm 1.4^{\ddagger}$ & $40 \pm 5$ & $+9.5 \pm 1.7 *$ & $40 \pm 4$ & $-3.4 \pm 0.7^{*}$ \\
\hline Ornitine & $67 \pm 6$ & $-0.4 \pm 0.9$ & $68 \pm 11$ & $+2.8 \pm 1.7$ & $68 \pm 9$ & $+0.9 \pm 1$ \\
\hline Lysine & $134 \pm 9$ & $-0.4 \pm 1.5$ & $131 \pm 13$ & $+20.6 \pm 5.8^{\S}$ & $132 \pm 10$ & $-9 \pm 2.4^{\S}$ \\
\hline Histidine & $85 \pm 8$ & $+1.5 \pm 2.3$ & $72 \pm 5$ & $+7.2 \pm 2.7^{\ddagger}$ & $74 \pm 4$ & $-3.2 \pm 1^{\S}$ \\
\hline Arginine & $59 \pm 5$ & $-5.2 \pm 1.7^{\ddagger}$ & $59 \pm 5$ & $+13 \pm 3.7^{\S}$ & $63 \pm 4$ & $-5.4 \pm 2.5^{\ddagger}$ \\
\hline Glutamine & $475 \pm 20$ & $+19.2 \pm 5.6^{\ddagger}$ & $449 \pm 28$ & $+76 \pm 21.6^{\S}$ & $456 \pm 23$ & $-20.7 \pm 8.2^{\S}$ \\
\hline Glutamate & $144 \pm 8$ & $-4.0 \pm 1.5^{\ddagger}$ & $143 \pm 9$ & $-53 \pm 12^{\S}$ & $141 \pm 7$ & $+22 \pm 3 *$ \\
\hline
\end{tabular}

Arterial values are reported separately, because renal and hepatic veins were not sampled in all subjects. ${ }^{\ddagger} P<0.05 ;{ }^{\S} P<0.01 ; * P<0.001$ significantly different from zero.

$\mathrm{m}^{2}$. Leucine concentration in the renal vein was slightly although significantly greater (by $\approx 2 \%, P<0.05$ ) than in the artery (Table I), indicating net amino acid release. In contrast, renal vein phenylalanine concentration was significantly lower (by $\approx 9 \%, P<0.01$ ) than in the artery, indicating net uptake.

Amino acid SA and enrichments in the renal vein were significantly lower (by $\approx 10-15 \%, P<0.01)$ than in the artery, indicating amino acid production (Table I). Conversely, ${ }^{14} \mathrm{C}$ leucine, ${ }^{15} \mathrm{~N}$-leucine, and ${ }^{3} \mathrm{H}$-phenylalanine isotope concentrations in the artery were greater $(P<0.05$ to $P<0.01)$ (by $\approx 11 \%$, $\approx 7 \%$, and $\approx 22 \%$, respectively) than in the renal vein, indicating simultaneous amino acid uptake. Interestingly, the A-V isotope concentration differences across the kidneys were lower $(P<0.05$ or less) than those measured across either the splanchnic area or the legs (see below).

The kidney took up KIC from the circulation with a relatively high fractional extraction $(\approx 12 \%)$ (Table I). However, both ${ }^{14} \mathrm{C}-\mathrm{KIC}$ isotope concentration and SA in the renal vein were lower (by $-20 \%$ and $-8 \%$, respectively, $P<0.01$ ) than the corresponding arterial values, indicating simultaneous release of unlabeled KIC.

${ }^{14} \mathrm{C}$-bicarbonate concentration in the renal vein was $\approx 12 \%$ greater $(P<0.02)$ than in the artery, indicating ${ }^{14} \mathrm{CO}_{2}$ production from ${ }^{14} \mathrm{C}$-leucine oxidation.

The kidney also took up citrulline and glutamine, while it released threonine, serine, alanine, cysteine, tyrosine, and arginine in addition to leucine (Table II). The A-V differences of the other amino acids were not significant.

Splanchnic bed. Blood flow across the splanchnic area was $1,293 \pm 137 \mathrm{ml} / \mathrm{min} \cdot 1.73 \mathrm{~m}^{2}$. Leucine and phenylalanine concentrations in the hepatic vein were significantly lower (by $\approx 5 \%$ and by $\approx 13 \%$, respectively, $P<0.05$ ) than in the artery (Table I), indicating net splanchnic amino acid uptake. Fractional extraction of leucine $(\approx 4 \%)$ was significantly lower (by approximately two-thirds) $(P<0.03)$ than that of phenylalanine $(\approx 12 \%)$. ${ }^{14} \mathrm{C}$-Leucine, ${ }^{15} \mathrm{~N}$-leucine, and ${ }^{3} \mathrm{H}$-phenylalanine isotope concentrations in the artery were $\approx 28 \%, \approx 60 \%$, and $\approx 62 \%$ greater, respectively $(P<0.001)$, than those of the hepatic vein, also indicating amino acid uptake. However, amino acid SA and enrichments in the hepatic vein were significantly lower (by $\approx 20-33 \%$ ) than in the artery, indicating simultaneous amino acid release (Table I).

KIC substrate and ${ }^{14} \mathrm{C}$-isotope concentrations in the hepatic vein were $\approx 10 \%$ and $\approx 20 \%$ greater $(P<0.05$ and $P<$ 0.01 , respectively) than those in the artery (Table I). KIC SA in the hepatic vein was slightly (by $\approx 6 \%$ ) but insignificantly greater than in the artery $(P=0.29)$. Taken together, these data indicated production as well as net release of KIC by splanchnic organs into the hepatic vein. ${ }^{14} \mathrm{C}$-Bicarbonate concentration was $\approx 6 \%$ greater $(P<0.03)$ in the hepatic vein than in the artery, indicating ${ }^{14} \mathrm{CO}_{2}$ production from splanchnic ${ }^{14} \mathrm{C}$-leucine oxidation.

The splanchnic area also took up threonine, serine, alanine, valine, cysteine, tyrosine, lysine, histidine, arginine, and glutamine, while it released citrulline and glutamate (Table II).

Legs. Blood flow across the combined two legs was $901 \pm 99 \mathrm{ml} / \mathrm{min} \cdot 1.73 \mathrm{~m}^{2}$. Leucine and phenylalanine concentrations in the femoral vein were significantly greater (by $\approx 3 \%, P<$ 0.03 , and by $\approx 14 \%, P<0.001$, respectively) than in the artery (Table I), indicating net amino acid release. Amino acid SA and enrichments in the femoral vein were significantly lower (by $\approx 17-37 \%, P<0.01$ ) than in the artery, also indicating amino acid production (Table II). In contrast, ${ }^{14} \mathrm{C}$-leucine, ${ }^{15} \mathrm{~N}$-leucine, and ${ }^{3} \mathrm{H}$-phenylalanine isotope concentrations in the artery were greater $(P<0.001)$ (by $\approx 18 \%, \approx 50 \%$, and $\approx 21 \%$, respectively) than those in the hepatic vein, indicating simultaneous amino acid uptake. KIC substrate and ${ }^{14} \mathrm{C}$-isotope concentrations, as well as KIC SA in the femoral vein, were not different from those in the artery (Table I). ${ }^{14} \mathrm{C}$-Bicarbonate concentration was $\approx 10 \%$ greater $(P<0.03)$ in the femoral vein than in the artery, consistent with ${ }^{14} \mathrm{C}$-leucine oxidation by the legs.

The legs released several other amino acids, such as threonine, serine, glycine, alanine, valine, isoleucine, tyrosine, 
Table III. Leucine and KIC Kinetics ( $\mu \mathrm{mol} / \mathrm{min} \cdot 1.73 \mathrm{~m}^{2}$ ) across the Kidneys, the Splanchnic Bed, and the Legs, Calculated with the Six-compartment Model (25)

\begin{tabular}{|c|c|c|c|}
\hline & Kidneys & Splanchnic & Legs \\
\hline Leu from Art (F1) & $125.7 \pm 10.0$ & $171.9 \pm 22.8$ & $127.9 \pm 16.3$ \\
\hline Leu into cell (F2) & $10.1 \pm 2.5$ & $61.8 \pm 10.5$ & $42.9 \pm 5.3$ \\
\hline Leu out of cell (F3) & $11.9 \pm 2.5$ & $54.4 \pm 9.5^{*}$ & $46 \pm 6.2^{\ddagger}$ \\
\hline Leu into vein $(\mathrm{F} 4)$ & $127.5 \pm 10.4$ & $164.6 \pm 21.6$ & $130.9 \pm 16.8$ \\
\hline Leu from PD (F5) & $16.8 \pm 5.1$ & $32.1 \pm 9.9$ & $27.4 \pm 6.6$ \\
\hline Leu into PS (F6) & $11.6 \pm 5.1^{\S}$ & $30.8 \pm 11.5$ & $20.3 \pm 6.5^{\S}$ \\
\hline $\mathrm{Leu} \rightarrow \mathrm{KIC}(\mathrm{F} 7)$ & $3.6 \pm 5.0$ & $30.5 \pm 7.9$ & $27.9 \pm 7.2$ \\
\hline $\mathrm{KIC} \rightarrow$ Leu (F8) & $0.2 \pm 4.4^{\|}$ & $21.8 \pm 6.3^{\pi}$ & $23.9 \pm 6.5^{\pi}$ \\
\hline Leu Ox (F9) & $6.7 \pm 0.9$ & $4.5 \pm 2.1$ & $4.7 \pm 1$ \\
\hline KIC from Art (F10) & $29.6 \pm 3.3$ & $38.5 \pm 3.2$ & $28.3 \pm 3.2$ \\
\hline KIC into vein (F11) & $26.3 \pm 2.5 * *$ & $42.7 \pm 3.1^{\text {辣 }}$ & $27.6 \pm 3.1$ \\
\hline $\operatorname{Leu}_{\mathrm{Art} \rightarrow \text { Vein }}(\mathrm{F} 12)$ & $115.5 \pm 9.2$ & $110.2 \pm 15.3$ & $84.9 \pm 12.8$ \\
\hline Net balance (F5-F6) & $-5.2 \pm 1.3^{\S \S}$ & $-1.3 \pm 3.9$ & $-7.1 \pm 2.4^{\S \S}$ \\
\hline
\end{tabular}

Art, artery; PD, protein degradation; PS, protein synthesis; Ox, oxidation; Leu $\rightarrow$ KIC, leucine deamination to KIC; KIC $\rightarrow$ Leu, KIC reamination to leucine; $\mathrm{Leu}_{\mathrm{Art} \rightarrow \mathrm{Vein}}$, unmetabolized leucine released directly from artery into the vein. ${ }^{\ddagger} P<0.05$ and ${ }^{*} P<0.02, \mathrm{~F} 3$ vs. F2; ${ }^{\circledR} P<0.02$, F6 vs. F5; $\| P<0.05$, and ${ }^{\mathbb{I}} P<0.02$, F8 vs. F7; $* * P<0.05$, and ${ }^{\ddagger} P<0.01$, F11 vs. F10; ${ }^{\S} P<0.01$ vs. zero.

lysine, histidine, arginine, and glutamine (Table II), while they took up cyst(e)ine and glutamate.

Arterial plasma insulin and glucagon concentrations were stable throughout the study (insulin: $12 \pm 2 \mu \mathrm{U} / \mathrm{ml}$; glucagon: $99 \pm 10 \mathrm{pg} / \mathrm{ml})$.

\section{Organ leucine kinetics: Compartmental model data (Table III)}

Kidneys. Leucine release from proteolysis (F5) was $\approx 45 \%$ greater $(P<0.02)$ than disposal into protein synthesis $(\mathrm{F} 6)$. Therefore, the kidneys were at negative leucine, i.e., protein, balance by $\approx 5 \mu \mathrm{mol} / \mathrm{min} \cdot 1.73 \mathrm{~m}^{2}$ of leucine (Table III, Fig. 1 ). Intracellular leucine incorporation into kidney protein synthe-

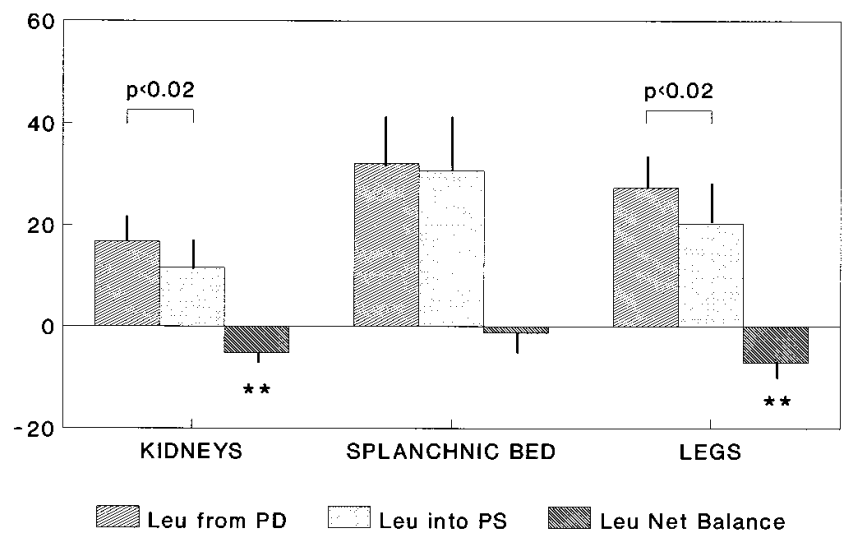

Figure 1. Protein degradation and synthesis (expressed in $\mu \mathrm{mol} /$ $\min \cdot 1.73 \mathrm{~m}^{2}$ of body surface) across the kidneys, the splanchnic area, and the legs, calculated using the six-compartment model of leucine and KIC (25). ** Significant difference (at the level of $P<0.01$ ) vs. zero.

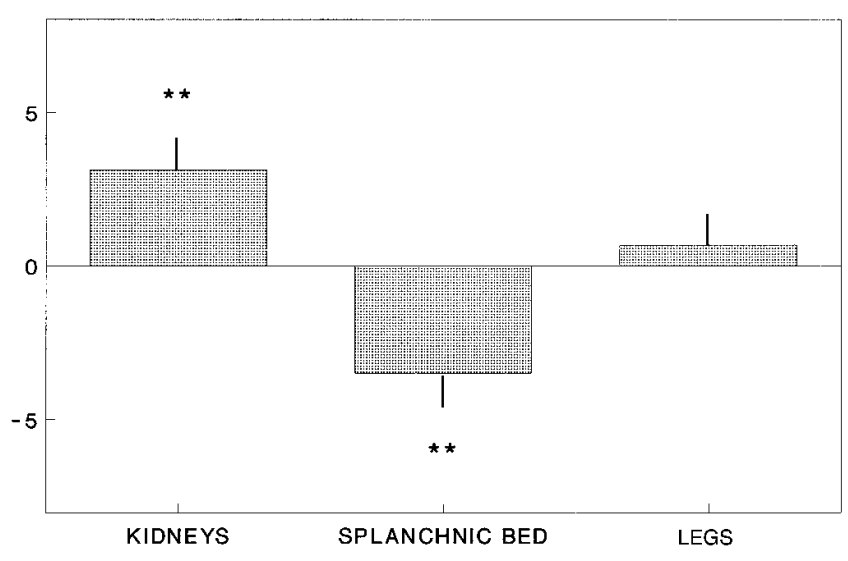

Figure 2. Net KIC balance (i.e., $R_{\mathrm{d}}-R_{\mathrm{a}}$ ) (expressed in $\mu \mathrm{mol} /$ $\min \cdot 1.73 \mathrm{~m}^{2}$ of body surface) across the kidneys, the splanchnic area and the legs. ** Significant difference (at the level of $P<0.01$ ) vs. zero.

sis represented $\approx 44 \%$ of total intracellular leucine appearance (i.e., the sum of leucine inflow from blood [F2], release from proteolysis [F5], and reamination from KIC [F8]). Leucine conversion into KIC was greater $(P<0.05)$ than KIC conversion into leucine, consistent with net leucine deamination to KIC. The rate of kidney leucine oxidation was $\approx 50 \%$ that of intracellular leucine incorporation into protein [F6]. Net KIC balance across the kidneys was positive (i.e., uptake was greater than release $)$, by about $\approx 3.3 \mu \mathrm{mol} / \mathrm{min} \cdot 1.73 \mathrm{~m}^{2}(P<$ 0.05 vs zero) (Table III, Fig. 2). Thus, the relatively high rate of leucine-carbon oxidation in the kidneys was quantitatively accounted for by net leucine deamination (i.e., the difference between [F7]-[F8]), as well as by the net positive KIC balance (Table III, Fig. 2).

Leucine inflow into cell (F2) was slightly $(-15 \%)$ although insignificantly smaller $(P=0.11)$ than outflow [F3]. Leucine inflow $[\mathrm{F} 2]$ represented only $\approx 6 \%$ of arterial leucine delivery. This fraction was significantly lower $(P<0.01$ by ANOVA) than that observed across both the splanchnic area and the legs (see below).

Splanchnic bed. In the splanchnic bed, the rates of leucine release from proteolysis and of incorporation into protein synthesis were similar. Therefore the splanchnic area was at zero leucine, i.e., protein, balance (Table III, Fig. 1). Leucine incorporation into protein synthesis represented $\approx 26 \%$ of total intracellular leucine appearance (i.e., the sum of leucine inflow from blood [F2], release from proteolysis [F5], and reamination from KIC [F8]).

Leucine conversion into $\mathrm{KIC}$ was $\approx 40 \%$ faster $(P<0.02)$ than KIC conversion into leucine (Table III). Net conversion of leucine to $\mathrm{KIC}$ was $\approx 9 \mu \mathrm{mol} / \mathrm{min} \cdot 1.73 \mathrm{~m}^{2}$. The rate of leucine oxidation was $\approx 15 \%$ that of leucine incorporation into protein $[\mathrm{F} 6]$ and $\approx 4 \%$ that of intracellular leucine appearance [F5]. The splanchnic area showed a net release of KIC (Fig. 2) of $\approx 4 \mu \mathrm{mol} / \mathrm{min} \cdot 1.73 \mathrm{~m}^{2}(P<0.01$ vs. zero $)$, a figure which was nearly equivalent to the rate of leucine oxidation (Table III). Since the rates of leucine release and incorporation from/ into protein were not different, the leucine loss across the splanchnic bed through net deamination and oxidation was quantitatively balanced by the net leucine uptake (i.e., the difference between leucine inflow [F2] minus outflow [F3]). In- 
deed, leucine inflow [F2] was $\approx 15 \%$ greater $(P<0.02)$ than outflow [F3]. Leucine inflow [F2] represented $\approx 36 \%$ of the arterial leucine delivery.

Legs. The rate of intracellular leucine release from proteolysis [F5] was greater $(P<0.02)$ than that of leucine incorporation into protein synthesis [F6], consistent with a negative leucine, i.e., protein, net balance (Table III, Fig. 1). Leucine incorporation into protein synthesis represented $\approx 28 \%$ of total intracellular leucine appearance (i.e., the sum of leucine inflow from blood [F2], release from proteolysis [F5], and reamination from KIC [F8]). Leucine conversion into $\mathrm{KIC}$ was $\approx 20 \%$ faster $(P<0.02)$ than KIC conversion into leucine. Net conversion of leucine to $\mathrm{KIC}$ was $\approx 5 \mu \mathrm{mol} / \mathrm{min} \cdot 1.73 \mathrm{~m}^{2}$. The rate of leucine oxidation was $\approx 27 \%$ that of intracellular leucine incorporation into protein [F6]. Net KIC balance was not different from zero (Fig. 2). Therefore, net leucine loss through transamination and subsequent oxidation was nearly matched by the difference between leucine release from proteolysis and inflow, minus utilization into protein synthesis and outflow. Leucine inflow [F2] represented $\approx 34 \%$ of arterial leucine delivery. Leucine inflow [F2] was $\approx 7 \%$ smaller $(P<0.05)$ than outflow [F3].

\section{Alternative leucine A-V models (Tables $I V$ and $V$ )}

The kinetic data calculated using Cheng's model (32) are shown on Table IV. The rates of leucine release from protein degradation and incorporation into protein synthesis in the splanchnic bed tended to be greater $(P=0.085$, and $P=0.13$, respectively, by the Student's paired $t$ test) than the corresponding six-compartment model estimates, while they were similar in the other organs. However, net leucine balance across organs was of the same magnitude using either model. In the legs, both leucine deamination and reamination rates were $\approx 60-70 \%$ greater $(P<0.01)$ with the Cheng model than with the compartmental model (see Tables III and IV). Also splanchnic leucine deamination and reamination rates were $\approx 50-70 \%$ greater with Cheng's model, although the difference was not statistically significant by paired tests. However, in the kidney there were no differences in the leucine transamination rates between the two models. The negative rates of Table IV were not different from zero. Net leucine deamination was of the same magnitude using either model in all organs.

Table $\mathrm{V}$ reports the leucine kinetic data calculated by also including $\mathrm{KIC}$ in organ leucine-carbon exchange (see Meth-

Table IV. Leu and KIC Kinetics ( $\mu \mathrm{mol} / \mathrm{min} \cdot 1.73 \mathrm{~m}^{2}$ ) across the Kidneys, the Splanchnic Bed and the Legs, Calculated with the $A$-V Model Proposed by Cheng et al. (32)

\begin{tabular}{lccc}
\hline & Kidneys & Splanchnic bed & Legs \\
\hline Leu from breakdown & $13.3 \pm 4.7^{*}$ & $50.2 \pm 10.5$ & $27.9 \pm 7.1^{*}$ \\
Leu into synthesis & $9.1 \pm 5.3$ & $48.8 \pm 12.2$ & $20.8 \pm 8.1$ \\
Leu net balance & $-4.2 \pm 1.5^{\ddagger}$ & $-1.4 \pm 4.8$ & $-7.1 \pm 2.5^{\ddagger}$ \\
Leu oxidation & $6.7 \pm 0.9$ & $4.5 \pm 2.1$ & $4.7 \pm 1$ \\
Leu deamination & $-0.9 \pm 7.6$ & $45.6 \pm 16.4^{\S}$ & $46.0 \pm 12.2^{\S}$ \\
Leu reamination & $-3.4 \pm 6.5$ & $36.9 \pm 16.1$ & $42.1 \pm 11.5$ \\
Net transamination & $2.5 \pm 1.9$ & $8.8 \pm 3.1^{\ddagger}$ & $3.9 \pm 1.5^{\ddagger}$ \\
& & &
\end{tabular}

See Methods for details. ${ }^{*} P<0.05$, breakdown vs. synthesis; ${ }^{\S} P<0.05$, deamination vs. reamination; ${ }^{\ddagger} P<0.05$, significantly different from zero.
Table V. Leucine and Phenylalanine Kinetics across the Kidneys, the Splanchnic Bed, and the Legs, Calculated with Noncompartmental A-V models

\begin{tabular}{lccc}
\hline & Kidneys & Splanchnic bed & Legs \\
\hline Leucine data & & & \\
Leu-C $R_{\mathrm{a}}$ & $16.9 \pm 5.1$ & $37.8 \pm 9.9$ & $27.7 \pm 6.7$ \\
Leu-C $R_{\mathrm{d}}$ & $18.3 \pm 5.2$ & $41.3 \pm 10.3$ & $25.1 \pm 6.3$ \\
Leu-C Ox & $6.7 \pm 0.9$ & $4.5 \pm 2.1$ & $4.1 \pm 1$ \\
Leu-C $\rightarrow$ PS & $11.6 \pm 5.1^{*}$ & $35.8 \pm 10.2$ & $20.4 \pm 6.5^{*}$ \\
NB & $-5.3 \pm 1.3^{*}$ & $-1.9 \pm 3.7$ & $-7.2 \pm 2.6^{*}$ \\
Phenylalanine & & & \\
$R_{\mathrm{a}}$ & $4.4 \pm 1.6$ & $13.1 \pm 2.1$ & $10.1 \pm 1.3$ \\
$R_{\mathrm{d}}$ & $8.1 \pm 2.4^{\ddagger}$ & $17.9 \pm 2.7^{\S}$ & $5.1 \pm 1.2^{\S}$ \\
NB & $+3.7 \pm 1.7^{\|}$ & $+4.9 \pm 1.2$ & $-5.0 \pm 0.7^{ף}$ \\
& & & \\
\hline
\end{tabular}

The leucine data were expressed as leucine-carbon $(\mathrm{Leu}-\mathrm{C})$ kinetics, i.e., it was calculated including KIC in organ uptake and release, and using venous KIC SA as the intracellular leucine precursor pool (see Methods for details). Phenylalanine kinetics was calculated using Gelfand's A-V model (3). $O x$; leucine oxidation; Leu-C $\rightarrow$ PS, rate of leucine carbon disposal into protein sythesis; NB, net leucine balance. All data are expressed as $\mu \mathrm{mol} / \mathrm{min} \cdot 1.73 \mathrm{~m}^{2} .{ }^{\ddagger} P<0.05 ;{ }^{\circledR} P<0.02 R_{\mathrm{d}}$ vs. $R_{\mathrm{a}}$; ${ }^{*} P<0.02$; $* * P<0.002$ PS vs. $R_{\mathrm{a}} ; \| P<0.05 ;{ }^{\pi} P<0.01$ significantly different from zero.

ods). Again, both the kidneys and the legs were at negative leucine-carbon, i.e., protein net balance, since release from proteolysis exceeded incorporation into protein synthesis. Conversely, the splanchnic area was at zero leucine, i.e., protein balance, since protein degradation was not different from protein synthesis. Therefore, there were some quantitative, but not qualitative, differences among estimates of organ protein synthesis and degradation obtained using the various leucine models.

Organ phenylalanine kinetics (Table V)

The kidneys were at positive phenylalanine balance by $\approx 4$ $\mu \mathrm{mol} / \mathrm{min} \cdot 1.73 \mathrm{~m}^{2}$, because $R_{\mathrm{d}}$ exceeded $R_{\mathrm{a}}(P<0.01)$. Also the splanchnic bed was at positive phenylalanine balance, by $\sim 5 \mu \mathrm{mol} / \mathrm{min} \cdot 1.73 \mathrm{~m}^{2}(P<0.001)$. In contrast, leg phenylalanine $R_{\mathrm{a}}$ exceeded $R_{\mathrm{d}}(P<0.001)$ by $\sim 5 \mu \mathrm{mol} / \mathrm{min} \cdot 1.73 \mathrm{~m}^{2}$.

Fractional uptake of leucine and phenylalanine across organs

In both kidneys and splanchnic area, fractional phenylalanine uptake was significantly greater than that of either leucine or the sum of leucine plus KIC (Table VI). Actually, in the kid-

Table VI. Fractional Uptake of Leucine, of the Sum of Leucine and KIC, and of Phenylalanine across Kidneys, the Splanchnic Bed, and the Legs

\begin{tabular}{lccc}
\hline & Kidneys & Splanchnic bed & Legs \\
\hline Leucine & $9.3 \pm 2.5$ & $21.8 \pm 2.2$ & $15.5 \pm 2.5$ \\
Leucine+KIC & $10.7 \pm 2.4^{*}$ & $14.9 \pm 2.9^{*}$ & $13.6 \pm 2.4^{*}$ \\
Phenylalanine & $19.9 \pm 4.2^{\ddagger}$ & $36.7 \pm 2.7^{\S}$ & $15.5 \pm 4.1$
\end{tabular}

${ }^{\ddagger} P<0.05 ;{ }^{\S} P<0.01$ phenylalanine vs. leucine fractional uptake within the same organ; ${ }^{*} P<0.05$ leucine vs. leucine $+\mathrm{KIC}$ fractional uptake within the same organ. 
Table VII. Whole-body Leucine (Using Both the Primary and the Reciprocal Pool Model) and Phenylalanine Kinetics

\begin{tabular}{lcc}
\hline & $\mu \mathrm{mol} / \mathrm{min} \cdot 1.73 \mathrm{~m}^{2}$ & $\mu \mathrm{mol} / \mathrm{min} \cdot \mathrm{kg}$ \\
\hline $\begin{array}{l}\text { Leu } R_{\mathrm{a}} \\
\quad(\text { primary pool) }\end{array}$ & $143.4 \pm 12.4$ & \\
Leu $R_{\mathrm{a}}{ }^{*}$ & & $2.25 \pm 0.19$ \\
$\quad($ reciprocal pool) & $167.1 \pm 18.2$ & $2.69 \pm 0.31$ \\
Leu N $R_{\mathrm{a}}{ }^{*}$ & $176 \pm 11$ & $2.75 \pm 0.14$ \\
Leu Ox & $29.1 \pm 4.9$ & $0.47 \pm 0.08$ \\
Leu to protein & $137.9 \pm 14.7$ & $2.22 \pm 0.26$ \\
Phe $R_{\mathrm{a}}$ & $59.9 \pm 5.5$ & $0.97 \pm 0.09$ \\
& & \\
\hline
\end{tabular}

*In one subject, blood KIC concentrations and SA and ${ }^{15} \mathrm{~N}$-leucine enrichments were not measured.

neys leucine was released rather than taken up (Table II). In contrast, in the legs fractional uptake of the two amino acids was similar (Table VI).

\section{Organ contributions to whole-body leucine kinetics}

Table VII reports whole-body leucine $R_{\mathrm{a}}$ (primary and reciprocal pool model), oxidation, incorporation into protein synthesis, as well as phenylalanine $R_{\mathrm{a}}$. While the data of leucine kinetics are well in the range of published reports $(1,4,5,12$, $13,20,21,40-42), R_{\mathrm{a}}$ of phenylalanine was somewhat higher than that expected $(13,20,44-46)$. Such a high rate may be related to whole-blood measurements of phenylalanine SA, which was somewhat lower than in plasma.

The percent contributions by kidneys, splanchnic organs, and estimated total skeletal muscle, calculated using the compartment model, to whole-body leucine kinetics are depicted in Fig. 3. The two kidneys accounted for $11.4 \pm 4.2 \%$ of whole-body proteolysis, for $10.1 \pm 4.5 \%$ of protein synthesis, and for $25.6 \pm 6.0 \%$ of leucine oxidation. The splanchnic area accounted for $22.1 \pm 6.7 \%$ of whole-body proteolysis, for $26.8 \pm$ $10.2 \%$ of protein synthesis, and for $17.9 \pm 7.3 \%$ of leucine oxidation. Estimated total skeletal muscle accounted for $35.8 \pm$

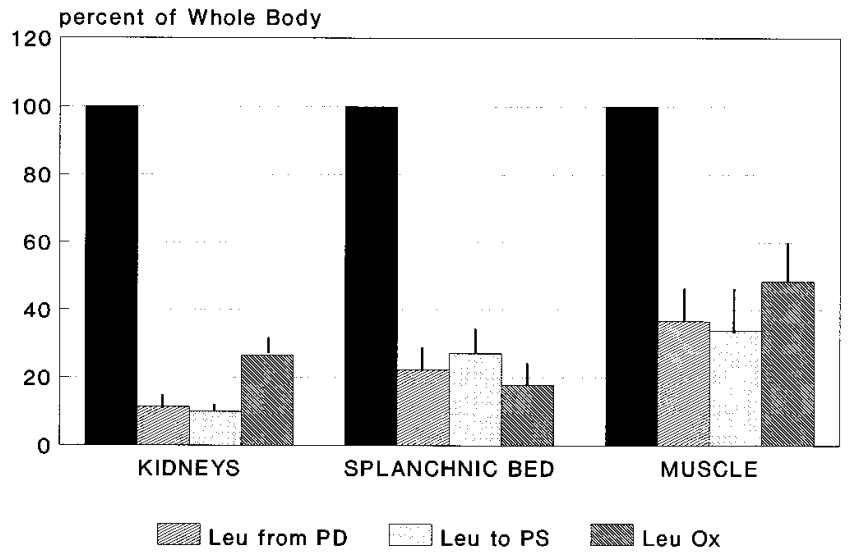

Figure 3. Percent contributions by kidneys, splanchnic area, and estimated total skeletal muscle (calculated using the six-compartment model) to body leucine release from protein degradation (Leu from $P D$ ), leucine disposal into protein synthesis (Leu to $P S$ ), and oxidation $(O x)$ (all calculated using the reciprocal pool model of leucine).
$10.6 \%$ of whole-body proteolysis, for $32.2 \pm 12.9 \%$ of protein synthesis, and for $48.3 \pm 12.9 \%$ of leucine oxidation. The three regions together accounted for $\approx 70 \%$ of whole-body proteolysis, for $\approx 70 \%$ of whole-body protein synthesis, and for $\approx 90 \%$ of whole-body leucine oxidation. Using Cheng's model, the contributions by the splanchnic bed to body protein degradation and synthesis rose to $\approx 35 \%$ and to $\approx 39 \%$, respectively, while they were grossly similar in the two other organs.

\section{Discussion}

This study reports the first estimates of kidney protein turnover in humans, both in absolute terms and in comparison with those of splanchnic organs and the legs. Organ protein degradation and synthesis were calculated through the kinetics of the essential amino acid leucine using a six-compartment leucine and KIC model. The data were analyzed also using noncompartmental leucine models.

\section{Kidney protein synthesis and degradation}

Despite their small mass, the kidneys play an important role in amino acid homeostasis $(1,4-6,9)$. Both leucine transaminase and oxidase activities were found to be high in kidney tissue preparations $(5,6,47)$. From in vitro studies fractional turnover rates of tubular proteins were estimated to be $\approx 30 \% / \mathrm{d}$ $(5,6)$. However, no study had previously investigated renal amino acid (and protein) kinetics in humans.

Our data show directly that kidney protein turnover is high. Despite the fact that renal weight is $\sim 1 \%$ that of total skeletal muscle, and $<13 \%$ that of splanchnic organs $(48,49)$, the rates of leucine release from kidney protein degradation and uptake for kidney protein synthesis (six-compartment model) ranged between $\approx 12$ and $\approx 17 \mu \mathrm{mol} / \mathrm{min} \cdot 1.73 \mathrm{~m}^{2}$, which corresponded to one-third/one-half of protein degradation and synthesis estimated either in total skeletal muscle or across the entire splanchnic area. The kidneys accounted for significant fractions of whole-body protein degradation $(\approx 11 \%)$, synthesis $(\approx 10 \%)$, and leucine oxidation $(\approx 26 \%)$ (Fig. 3$)$. These quantitative data may have practical implications in the interpretation of results from studies of whole-body protein turnover in patients with chronic renal failure. In these patients, loss of active renal metabolic activities could account for the observed reduction of whole-body leucine flux and oxidation (50). Furthermore, since protein synthesis is an energy-requiring process (51), such a high protein synthetic rate by the kidney could explain, at least in part, its high oxygen consumption (48).

Another relevant observation of our study is that renal amino acid, i.e., protein balance, was negative in the postabsorptive state (Fig. 1). Actually, protein degradation ([F5]) was $\approx 45 \%$ greater than synthesis ([F6]). The apparent net kidney leucine loss ranged between $\approx 5$ and $8 \mu \mathrm{mol} / \mathrm{min}$, or $\approx 7-12$ $\mathrm{mmol} / \mathrm{d}$ (Fig. 1). This figure appears to be high with respect to the estimated kidney protein content (52). However, a possible, consistent overestimation of kidney negative protein balance may arise from unaccounted intrarenal degradation of filtered peptides, polypeptides and low molecular weight proteins, which may occur in the proximal tubule through the lysosome proteolytic system (53). Thus, it is possible that the actual rate of kidney protein degradation is much less than what is apparent from the data. Our experimental approach does not enable us to quantitate the potential recycling of leucine (as well as of other amino acids) derived from intrarenal protein degrada- 
tion. Nevertheless, the measurements of kidney protein synthesis and of leucine oxidation should be correct.

The net KIC extraction by the kidneys was relatively high $\left(\approx 3.3 \mu \mathrm{mol} / \mathrm{min} \cdot 1.73 \mathrm{~m}^{2}\right)$, corresponding to $\approx 11 \%$ of arterial delivery (Fig. 2). Interestingly, renal extraction accounted for the majority $(\approx 70 \%$ ) of net KIC release by the splanchnic bed (Fig. 2), suggesting an important KIC trafficking between these two regions. Our data are thus compatible with the operation of a splanchnic-kidney KIC cycle in vivo in humans. The KIC extracted by the kidneys was likely used for energy, since KIC reamination to leucine was nearly undetectable (Table III). The extracted KIC, combined with net leucine deamination (i.e., [F7] - [F8]) $\left(3.4 \pm 1.3 \mu \mathrm{mol} / \mathrm{min} \cdot 1.73 \mathrm{~m}^{2}, P<0.05 \mathrm{vs}\right.$. zero), quantitatively accounted for renal leucine oxidation $(\approx 6.5$ $\mu \mathrm{mol} / \mathrm{min} \cdot 1.73 \mathrm{~m}^{2}$ ), as otherwise required by the mass-balance equations of the compartmental model.

About one-fourth of whole-body leucine oxidation took place in the kidneys (Fig. 3). As discussed above, a significant fraction of renal leucine oxidation might have arisen from recycled leucine, therefore it might not reflect renal protein catabolism. Studies in vitro have shown that the kidney is rich in all the enzymatic machinery involved in leucine catabolism and/or oxidation, in particular in the medullary thick ascending limb (54). Whatever its source could be, oxidation of leucine (as well as of other amino acids) in this nephron segment may provide energy to sustain active ion transport (48).

Intrarenal leucine incorporation into proteins represented $\approx 43 \%$ of total intracellular leucine appearance (i.e., the sum of leucine inflow from blood [F2], from protein degradation [F5], and from KIC reamination [F8]) (Table III). Such a fraction was nearly twofold greater than that calculated across either the splanchnic area $(\approx 25 \%)$ or estimated total skeletal muscle $(\approx 22 \%)$. These data suggest a greater dependency of kidney protein synthesis on the leucine supplied from proteolysis rather than from arterial delivery, suggesting a high protein anabolic efficiency and/or an extensive intracellular leucine recycling from different sources, as suggested above.

In the kidneys, the rate of leucine deamination was markedly lower than that calculated in either skeletal muscle $(P<$ $0.005)$ or the splanchnic area $(P<0.15)$ (Table III). Also, the rate of renal leucine reamination to KIC [F8] was lower than that measured across either muscle $(P<0.025)$ or splanchnic tissues $(P<0.15)$ (Table III). Although these renal transamination rates may appear surprisingly low because of the expected high leucine transaminase activity of kidney tubules (47), they would be high if related to the estimated small kidney protein mass.

Fractional ${ }^{15} \mathrm{~N}$-leucine extraction across the kidneys $(\approx 9 \%)$ was lower $(P<0.001)$ than that determined across either the legs or the splanchnic area $(\approx 35 \%)$ (Table I). Consequently, the calculated leucine inflow from blood to cell [F2] represented only $\approx 8 \%$ of arterial leucine delivery [F1], a fraction which was much smaller $(P<0.001)$ than that observed either in muscle or in the splanchnic area $(\approx 35 \%)$. Such a low fractional extraction of leucine may depend on several factors. One could be the high renal blood flow, both absolute and relative to the small kidney mass, which could limit amino acid extractions. Another could be due to a possible recycling into vein of the ${ }^{15} \mathrm{~N}$-leucine tracer, upon which trans-membrane leucine exchange (F2 and F3), as well as leucine and KIC interconversions (F7 and F8), are calculated (see Methods). A high ${ }^{15} \mathrm{~N}$-nitrogen recycling would indeed lead to underestimation of these rates (25). It should be observed that ${ }^{15} \mathrm{~N}$-nitrogen could recycle either through shuttling of unmodified ${ }^{15} \mathrm{~N}$-leucine molecules across the cell membrane or through KIC reamination to leucine. The potential recycling via KIC might be greater with the mono-labeled ${ }^{15} \mathrm{~N}$-leucine tracer, used in this study, than with the di-labeled ${ }^{15} \mathrm{~N},{ }^{13} \mathrm{C}$-leucine tracer used by others $(32,55,56)$. The design of our study does not allow for the exclusion of any of these possibilities. However, it should be observed that fractional extractions of the ${ }^{14} \mathrm{C}-\mathrm{leu}-$ cine and ${ }^{3} \mathrm{H}$-phenylalanine tracers also were low across the kidneys (see Results), suggesting an underlying common metabolic characteristic of renal tissues.

\section{Splanchnic protein synthesis and degradation}

Splanchnic amino acid and protein turnover had been investigated previously in humans using a variety of techniques $(1,4$, $12,13,29,30,45,46,57)$. In this study, we have compared splanchnic protein degradation and synthesis, net protein balance, leucine transmembrane exchange, oxidation, and bidirectional leucine interconversion with KIC with the corresponding rates measured across the kidneys and the legs in postabsorptive humans.

Our data show that, in the postabsorptive state, splanchnic protein balance was neutral, since protein degradation was not different from synthesis (Table III, Fig. 1). In contrast, in muscle protein degradation exceeded synthesis, confirming many previous observations $(3,12,21,44,58-61)$. Thus, at least under conditions of mild substrate deprivation such as those of the overnight fast, a net loss of visceral proteins did not occur, likely because amino acids were supplied to the splanchnic area by peripheral tissues such as skeletal muscle. This concept was supported not only by the leucine kinetic data but also by the behavior of net balance of several amino acids, which was negative in muscle but positive (i.e., in the direction of net uptake) across the splanchnic bed (Table II). This latter finding is in agreement with previous observations $(30,57)$.

By assuming that average leucine content of splanchnic proteins is $\sim 9 \%(1,4,62)$, total splanchnic protein synthesis would correspond to $\approx 70$ grams/d. This figure, which includes both gut and liver protein synthesis, is in good agreement with a recent organ catheterization/isotope infusion study performed in insulin-treated euglycemic diabetic subjects (17), who might behave as metabolically normal at euglycemia. In relative terms and using the six-compartment model, splanchnic protein synthesis accounted for a significant fraction $(\approx 27 \%)$ of whole-body protein synthesis (Fig. 3), nearly matching that contributed by total skeletal muscle $(\approx 33 \%)$.

The leucine used for protein synthesis was $\approx 50 \%$ the rate of leucine inflow from artery (Table III), a fraction similar to that observed in muscle $(\approx 45 \%)$ but lower than that of the kidneys $(\approx 100 \%$ ) (see above), suggesting a high dependence of protein synthesis from arterial leucine delivery in both visceral and muscle tissues. This is in agreement with studies showing that, at least in muscle, leucyl-tRNA enrichment is intermediate between that of intracellular free leucine and of plasma leucine $(35,63)$. In absolute terms, net leucine deamination in estimated total skeletal muscle $(\approx 9.4 \mu \mathrm{mol} / \mathrm{min} \cdot 1.73$ $\mathrm{m}^{2}$ ) was quantitatively similar to that of the splanchnic area $(\approx 9.3$ $\mu \mathrm{mol} / \mathrm{min} \cdot 1.73 \mathrm{~m}^{2}$ ), because of the high total muscle mass. It is interesting to note that these in vivo quantitative data are not in agreement with the common concept that muscle is the major site of leucine transamination $(1,14,15)$, but they underline 
the important contribution also by splanchnic organs to leucine-KIC interconversions.

Splanchnic leucine oxidation $\left(\approx 4.5 \mu \mathrm{mol} / \mathrm{min} \cdot 1.73 \mathrm{~m}^{2}\right)$ was quantitatively similar to net $\mathrm{KIC}$ release $(\approx 4.7 \mu \mathrm{mol} /$ $\min \cdot 1.73 \mathrm{~m}^{2}$ ). Thus, about one-half of splanchnic net leucine conversion to $\mathrm{KIC}\left(\approx 9 \mu \mathrm{mol} / \mathrm{min} \cdot 1.73 \mathrm{~m}^{2}\right)$ was oxidized locally, whereas the remaining one-half was exported as KIC (Fig. 2), likely to be used by other organs, mainly the kidneys. In contrast, in muscle the leucine deaminated to KIC was entirely oxidized locally, since no net KIC release was observed. On the whole, splanchnic tissues were more prone than skeletal muscle to diverge leucine towards either oxidation or KIC production.

The total amount of leucine oxidized by the splanchnic area $\left(\approx 4.5 \mu \mathrm{mol} / \mathrm{min} \cdot 1.73 \mathrm{~m}^{2}\right)$ was about one-half of that oxidized by total skeletal muscle $\left(\approx 9.4 \mu \mathrm{mol} / \mathrm{min} \cdot 1.73 \mathrm{~m}^{2}\right)$. From in vitro studies $(14,15)$, it was reported that the oxidative capacity of the liver was higher than that of muscle. Although our cumulative in vivo data indicate that the majority of leucine oxidation occurs in muscle, they are not in contrast with in vitro findings, if one considers that the estimated weight either of the liver $(\approx 1.5 \mathrm{~kg})$ or of total visceral organs $(\approx 2.6 \mathrm{~kg})(49)$ in an $\approx 69-\mathrm{kg}$ human (i.e., the mean weight of our subjects) are respectively, $\approx 5.4 \%$ and $\approx 9.4 \%$ the weight of skeletal muscle (which is $\approx 40 \%$ of whole-body weight, or $\approx 28 \mathrm{~kg}$ in $69-\mathrm{kg}$ subjects) (2). Thus, the rate of leucine oxidation, if expressed per gram of tissue protein, would be very high in splanchnic tissues in agreement with in vitro findings $(14,15)$.

Leucine inflow from blood into splanchnic intracellular spaces represented $\approx 35 \%$ of arterial leucine delivery, a fraction similar to that observed in muscle. Thus, also in the splanchnic area about two-thirds of the arterial leucine delivery bypassed intracellular metabolism, in agreement with recent animal studies (56).

The kidneys extracted phenylalanine, while they released leucine, in agreement with previous findings (9). In quantitative terms, the extracted phenylalanine was likely converted to tyrosine, possibly accounting for the observed net tyrosine release (Table II).

Fractional extraction of phenylalanine by the splanchnic bed and by the kidneys was significantly greater than that of leucine-carbon (Table VI), suggesting a selective amino acid handling by these organs. In contrast, leg fractional extractions of the two amino acids were similar (Table VI). A selective extraction of leucine versus phenylalanine by splanchnic organs had been shown recently in noninvasive, whole-body multiple isotope studies $(45,46)$. The greater phenylalanine extractions by kidney and splanchnic tissues might be related to their high phenylalanine catabolic, i.e., hydroxylase and oxidase, activities $(16,64)$.

The total contributions by the three catheterized regions to whole-body leucine kinetics ranged between $\approx 70 \%$ (protein synthesis and degradation) and $\approx 90 \%$ (leucine oxidation) (Fig. 3). It is likely that the remaining fractions were contributed by lungs, heart, and truncular skin as well as by head tissues.

We attempted to estimate fractional protein turnover rates of the three organs using the following assumptions $(4,48,49,52)$.

Kidneys. (a) Leucine percent abundance in mixed kidney proteins is $8.5 \%$ on molar basis (Garibotto, G., unpublished data); $(b)$ proteins account for $\approx 15 \%$ of kidney wet weight (52); (c) the mass (= weight) of the combined two kidneys is
3.8 grams \% per kg of body weight (4); therefore $(d)$ the estimated total leucine content of two kidneys is $\approx 37 \mathrm{mmol}$ in $69-\mathrm{kg}$ subjects $(4,48,49,52)$.

Splanchnic tissues. $(a)$ Leucine accounts for $\approx 9 \%$ (grams/ 100 grams) of mixed splanchnic proteins (62); this figure is the approximate mean between $\approx 8.2 \%$ (average leucine content of gut proteins) and $\approx 9.7 \%$ (average leucine content of liver proteins) calculated in pigs $(62) ;(b)$ the weight of visceral organs (liver and gut) is assumed to account for $\approx 4.1 \%$ of total body weight (49); $(c)$ proteins represent $\approx 20 \%$ of average weight of splanchnic tissues.

Legs. (a) Leucine accounts for 9\% (grams/100 grams) of skeletal muscle proteins $(1,4,62) ;(b)$ skeletal muscle accounts for $38 \%$ of total body nitrogen (49); (c) total body nitrogen can be calculated as 34 grams $/ \mathrm{kg}$ of whole body weight (49); (d) one leg corresponds to one-fourth of total skeletal muscle, therefore of nitrogen (1-4); and $(e)$ the possible contributions by skin (40) and bone to leg amino acid turnover are neglected, as discussed above.

In the kidney, estimated fractional protein degradation and synthesis were $\approx 61 \%$ and $\approx 42 \% / \mathrm{d}$, respectively, in the splanchnic area $\approx 13$ and $12 \% /$ day, in muscle $\approx 2.1$ and $1.5 \% / \mathrm{d}$. The latter muscle estimates are in good agreement with published reports in adult mammals $(1-4,12,21,32,34,35,37,40$, $44,49,61,65)$.

Although the comparison among various possible leucine kinetic models fell beyond the main purpose of this study, the choice of a model is itself important in the calculations of organ protein kinetics. As reported above, we have also used the noncompartmental model proposed by Cheng et al. (32), as well as a simpler A-V leucine and KIC approach (Table V). The data of net leucine, i.e., protein balance, as well as of net leucine deamination, were virtually the same using either model. However, we found some other interesting quantitative (although not qualitative) differences. Using Cheng's model, splanchnic protein synthesis and degradation tended to be greater than those calculated either with the six-compartment or with the simpler A-V leucine-carbon model (Tables III-V). Therefore, also the contribution to whole-body rates (see Results) as well as fractional splanchnic protein degradation $(\approx 21 \%$ vs. $\approx 13 \%)$ and synthesis ( $\approx 19 \%$ vs. $\approx 12 \%$ ) would be greater using this model. Transamination rates in the legs and the splanchnic area were also greater with Cheng's than with the six-compartment model. One reason for the lower rates estimated by the compartmental model may be the use of hepaticvenous KIC SA as the precursor pool to calculate intracellular rates, as opposed to venous leucine enrichment(s) used in Cheng's model (see Methods). Since the splanchnic bed produced both labeled and unlabeled KIC, venous KIC SA (used in the denominator) was greater than that of venous leucine, therefore splanchnic kinetic rates were lower with our model (see Tables III and IV). On the other hand, the reasons why leg transamination rates were lower using the compartmental than Cheng's model are not immediately apparent. They might depend on compartmentation and/or on the different way of calculation. Interestingly, however, the ratio between leucine loss through deamination versus protein synthesis $(\approx 2.98)$ measured across the forearm of fasted humans (66) was closer to our leg data also calculated with the same model $(\approx 2.21)$, than to those calculated with the compartmental model $(\approx 1.37)$. The persisting discrepancies might be due either to differences between leg versus forearm metabolism, to sampling in arterial 
blood (our study) versus arterialized plasma (66), or to the mono-labeled (our study) versus the di-labeled $(32,66)$ leucine stable isotope.

In conclusion, this study provides the first report of leucine, therefore, protein turnover, measured across the human kidney, also in comparison with that of the legs and the splanchnic area. These normal reference data could be useful in the investigation of the sites and the possible mechanisms of protein wasting, observed in many systemic as well as organ diseases.

\section{Acknowledgments}

Dr. Luisa De Biasi is acknowledged for her collaboration in some studies.

This study was supported by grants from the Italian National Research Council (CNR) (Target Project Biotechnology and Bioinstrumentatation; Target Project Aging, SP 3, $\mathrm{N}^{\circ}$ 92.00278, PF40).

\section{References}

1. Waterlow, J.C., P.J. Garlick, and D.J. Millward. 1978. Protein turnover in mammalian tissues and in the whole body. North Holland Publishing Co., Amsterdam, New York, Oxford.

2. Bjorntorp, P., and L. Sjostrom. 1978. Carbohydrate metabolism in man. Speculation and some quantitative consideration. Metab. Clin. Exp. 27:18531863.

3. Barrett, E.J., and R.A. Gelfand. 1989. The in vivo study of cardiac and skeletal muscle protein turnover. Diabetes Metab. Rev. 5:133-148.

4. Munro, H.N., and M.C. Crim. 1988. The proteins and amino acids. In Modern Nutrition in Health and Disease. M.E. Shils and V.R. Young, editors. Lea \& Febiger, Philadelphia. 1-37.

5. May, R., B. Logue, B. Edwards, and S. Patel. 1993. An in vitro method for the determination of protein turnover in incubated proximal tubule segments. Kidney Int. 43:1156-1159.

6. Goldspink, D.F., and F.J. Kelly. 1984. Protein turnover and growth in the whole body, liver and kidney of the rat from the foetus to senility. Biochem. J. 217:507-516.

7. Ogden, D.A. 1983. Consequences of renal donation in man. Am. J. Kidney Dis. 2:501-511.

8. Mogensen, C.E., and M.J.F. Andersen. 1973. Increased kidney size and glomerular filtration rate in early juvenile diabetes. Diabetes. 22:706-712.

9. Tizianello, A., G. Deferrari, G. Garibotto, G. Gurreri, and C. Robaudo. 1980. Renal metabolism of amino acids and ammonia in subjects with normal renal function and in patients with chronic renal insufficiency. J. Clin. Invest. 65: $1162-1173$.

10. Wahren, J., and P. Felig. 1975. Renal substrate exchange in human diabetes mellitus. Diabetes. 24:730-734.

11. Heys, S.D., K.G.M. Park, M.A. McNurlan, R.A. Keenan, J.D.B. Miller, O. Eremin, and P.J. Garlick. 1982. Protein synthesis rates in colon and liver. Stimulation by gastrointestinal pathologies. Gut. 33:976-981.

12. Gelfand, R.A., M.G. Glickman, P. Castellino, R.J. Louard, and R.A. DeFronzo. 1988. Measurement of $\mathrm{L}-\left[1-{ }^{14} \mathrm{C}\right]$ leucine kinetics in splanchnic and leg tissues in man. Diabetes. 37:1365-1372.

13. Fong, Y., D.E. Matthews, W. He, M.A. Marano, L.L. Moldawer, and S.F. Lowry. 1994. Whole body and splanchnic leucine, phenylalanine and glucose kinetics during endotoxemia in humans. Am. J. Physiol. 266:R419-R425.

14. Shinnick, F.L., and A.E. Harper. 1976. Branched-chain amino acid oxidation by isolated rat tissue preparations. Biochim. Biophys. Acta. 437:477-486.

15. Krebs, H.A., and P. Lund. 1977. Aspects of the regulation of the metabolism of branched chain amino acids. Adv. Enzyme Regul. 15:375-394.

16. Rosenberg, L.E., and C.R. Scriver. 1980. Disorders of amino acid metabolism. In Metabolic Control and Disease. P.K. Bondy and L.E. Rosenberg, editors. Saunders, Philadelphia. 707-710.

17. Nair, K.S., C. Ford, K. Ekberg, E. Fernqvist-Forbes, and J. Wahren. 1995. Protein dynamics in whole body and in splanchnic and leg tissues in type 1 diabetic patients. J. Clin. Invest. 95:2926-2937.

18. Metropolitan Life Foundation. 1983. Metropolitan height and weight tables. Stat. Bull. Metrop. Life Insur. Co. 64:2-17.

19. Classic, K.L., W.F. Schwenk, and M.W. Haymond. 1985. Radiobiological half-lives for carbon-14 and hydrogen-3 leucine in man. Proceedings of the 4th International Radiopharmaceutical Dosimetry Symposium, Oak Ridge, TN. 681-687.

20. Bier, D.M. 1989. Intrinsically difficult problems: the kinetics of body proteins and amino acids in man. Diabetes Metab. Rev. 5:111-152.

21. Tessari, P. 1994. Effects of insulin on whole-body and regional amino acid kinetics. Diabetes Metab. Rev. 10:253-285.
22. Horber, F.F., J. Kahl, L. Lecavalier, B. Krom, and M.W. Haymond. 1989. Determination of leucine and $\alpha$-ketoisocaproic acid concentrations and specific activity in plasma and of leucine specific activity in proteins using high performance liquid chromatography. J. Chromatogr. 495:81-94.

23. Tessari, P., S. Inchiostro, M. Vettore, L. Sabadin, and G. Biolo. 1991. A fast HPLC method for the measurement of plasma concentration and specific activity of phenylalanine. Clin. Biochem. 24:425-428.

24. Schwenk, W.F., P.J. Berg, B. Beaufrere, J.M. Miles, and M.W. Haymond. 1984. Use of $t$-butyldimethylsilylation in the GC/MS analysis of physiologic compounds found in plasma using electron impact ionization. Anal. Biochem. 141:101-109.

25. Tessari, P., S. Inchiostro, M. Zanetti, and R. Barazzoni. 1995. A model of skeletal muscle leucine kinetics measured across the human forearm. Am.J. Physiol. 269:E127-E136.

26. Herbert, V., L. Kam-Seng, C.W. Gottlieb, and J. Bleicher. 1965. Coated charcoal immunoassay of insulin. J. Clin. Endocrinol. \& Metab. 25:1375-1384.

27. Faloona, G.R., and R.H. Unger. 1985. Glucagon. In Methods in Hormone Radioimmunoassay. B.M. Jaffe and H.R. Behrmann, editors. Academic Press, New York. 317-330.

28. Bradley, S.E. 1948. Measurement of hepatic blood flow. Methods Med. Res. 1:199-207.

29. Wolff, J.E., E.N. Bergman, and H.H. Williams. 1972. Net metabolism of plasma amino acids by liver and portal-drained viscera. Am. J. Physiol. 223: 438-446.

30. Wahren, J., P. Felig, and L. Hagenfeldt. 1986. Effect of protein ingestion on splanchnic and leg metabolism in normal man and in patients with diabetes mellitus. J. Clin. Invest. 57:987-999.

31. Garibotto, G., G. Deferrari, C. Robaudo, S. Saffioti, A. Sofia, R. Russo, and A. Tizianello. 1995. Disposal of exogenous amino acids by muscle in patients with chronic renal failure. Am. J. Clin. Nutr. 62:136-142.

32. Cheng, K.N., F. Dworzak, G.C. Ford, M.J. Rennie, and D. Halliday. 1985. Direct determination of leucine metabolism and protein breakdown in humans using L- $\left[1-{ }^{13} \mathrm{C},{ }^{15} \mathrm{~N}\right]$ leucine and the forearm model. Eur. J. Clin. Invest. 15:349-353.

33. Horber, F.F., C.M. Horber-Feyder, S. Krayer, W.F. Schwenk, and M.W. Haymond. 1989. Plasma reciprocal pool specific activity predicts that of intracellular free leucine for protein synthesis. Am. J. Physiol. 257:E385-E399.

34. Watt, P.W., M.E. Corbett, and M.J. Rennie. 1992. Stimulation of protein synthesis in pig skeletal muscle by infusion of amino acids during constant insulin availability. Am. J. Physiol. 263:E453-E460.

35. Watt, P.W., Y. Lindsay, C.M. Scrimgeour, P.A. Chien, J.N.A. Gibson, D.J. Taylor, and M.J. Rennie. 1991. Isolation of aminoacyl-tRNA and its labeling with stable isotope tracers: use of human studies protein synthesis. Proc. Natl. Acad. Sci. USA. 88:5892-5896.

36. Layman, D.K., and R.R. Wolfe. 1987. Sample site selection for tracer studies applying a unidirectional circulatory approach. Am. J. Physiol. 253: E173-E178.

37. Quinn Baumann, P., W.S. Stirewalt, B.D. O'Rourke, D. Howard, and K.S. Nair. 1994. Precursor pools of protein synthesis: a stable isotope study in a swine model. Am. J. Physiol. 267:E203-E209.

38. Parhofer, K.G., P. Hugh, R. Barrett, D.M. Bier, and G. Schonfeld. 1991. Determination of kinetic parameters of apolipoprotein B metabolism using amino acids labeled with stable isotopes. J. Lipid Res. 32:1311-1323.

39. Cryer, D.R., T. Matsushima, J.B. Marsh, M. Yudkoff, P.M. Coates, and J.A. Cortner. 1986. Direct measurement of apolipoprotein B synthesis in human very low density lipoprotein using stable isotopes and mass spectrometry. J. Lipid Res. 27:508-516.

40. Biolo, G., A. Gastaldelli, X. Zhang, and R.R. Wolfe. 1994. Protein synthesis and breakdown in skin and muscle: a leg model of amino acid kinetics. Am. J. Physiol. 267:E467-E474.

41. Schwenk, W.F., B. Beaufrere, and M.W. Haymond. 1985. Use of reciprocal pool specific activities to model leucine metabolism in humans. Am. J. Physiol. 249:E646-E650.

42. James, W.P.T., P.J. Garlick, P.M. Sender, and J.C. Waterlow. 1976 Studies of amino acid and protein metabolism in normal man with $\mathrm{L}-\left(\mathrm{U}_{-}{ }^{14} \mathrm{C}\right)$ tyrosine. Clin. Sci. Mol. Med. 50:525-532.

43. Okamura, K., L. Wentzel, P. Williams, and P. Flakoll. 1991. The fixation of $\mathrm{CO}_{2}$ by the liver, gut, kidney and hindlimb in vivo. Diabetes. 40:195a. (Abstr.).

44. Denne, S.C., E.A. Litchely, Y.M. Liu, G. Brechtel, and A.D. Baron. 1981. Proteolysis in skeletal muscle and whole body in response to euglycemic hyperinsulinemia in normal adults. Am. J. Physiol. 261:E809-E814.

45. Biolo, G., P. Tessari, S. Inchiostro, D. Bruttomesso, C. Fongher, L. Sabadin, M. G. Fratton, A. Valerio, and A. Tiengo. 1992. Leucine and phenylalanine kinetics during mixed meal ingestion. A multiple tracer approach. Am. J. Physiol. 262:E455-E463.

46. Matthews, D.E., M.A. Marano, and R.G. Campbell. 1993. Splanchnic bed utilization of leucine and phenylalanine in humans. Am. J. Physiol. 264: E109-E118.

47. Ichihara, A., and E. Koyama. 1966. Transaminase of branched-chain amino acids. J. Biochem. 59:160-169.

48. Cohen Julius, J., and E. Kamm-Donald. 1976. Renal metabolism: relation to renal function. In The Kidney. B. Brenner and F.C. Rector, editors. 
Saunders, Philadelphia. 126-205.

49. Young, V.R. 1964. The role of skeletal and cardiac muscle in the regulation of protein metabolism. In Mammalian Protein Metabolism. H.N. Munro and J.B. Allison, editors. Vol. 4. Academic Press, New York. Chapter 40:585659.

50. Castellino, P., A. Solini, L. Luzi, J. Grant-Barr, D.J. Smith, A.S. Petrides, and R.A. DeFronzo. 1992. Glucose and amino acid metabolism in patients with chronic renal failure. Am. J. Physiol. 262:F168-F176.

51. Reeds, P.J., M.F. Fuller, and B.A. Nicholson. 1985. Metabolic basis of energy expenditure with particular reference to protein. In Substrate and Energy Metabolism in Man. J.S. Garrow and D. Halliday, editors. John Libbey, London, Paris. 46-57.

52. Lloyd, L.E., B.E. McDonald, and E.W. Crampton. 1978. General composition of the animal body and its tissues. In Fundamentals of Nutrition. 2nd

Ed. W.H. Freeman and Co. San Francisco. Section I, Chapter 4:36-46.

53. Maak, T. 1975. Renal handling of low molecular weight proteins. Am. J. Med. 58:57-64.

54. Tring-Trang-Tan, M.M., O. Levillain, and L. Bankir. 1988. Contribution of leucine to oxidative metabolism of the rat medullary thick ascending limb. Pflügers Archiv. 411:676-680.

55. Matthews, D.E., D.M. Bier, M.J. Rennie, R.H.T. Edwards, D. Halliday, D.J. Millward, and G.C. Clugston. 1980. Regulation of leucine metabolism in man: a stable isotope study. Science (Wash. DC). 214:1129-1131.

56. Yu, Y.M., D.A. Wagner, E.E. Tredget, J.A. Walaszewski, J.F. Burke, and V.R. Young. 1990. Quantitative role of splanchnic region in leucine metabolism: L- $\left[1-{ }^{13} \mathrm{C},{ }^{15} \mathrm{~N}\right]$ leucine and substrate balance studies. Am. J. Physiol. 259: E36-E51.

57. Eriksson, L.S., L. Hagelfeldt, P. Felig, and J. Wahren. 1983. Leucine uptake by splanchnic and leg tissues in man: relative independence of insulin levels. Clin. Sci. 65:491-498.
58. Tessari, P., S. Inchiostro, G. Biolo, E. Vincenti, and L. Sabadin. 1991. Effects of acute systemic hyperinsulinemia on forearm muscle proteolysis in healthy man. J. Clin. Invest. 88:27-33.

59. Gelfand, R.A., and E.J. Barrett. 1987. Effect of physiologic hyperinsulinemia on skeletal muscle protein synthesis and breakdown in man. J. Clin. Invest. 80:1-6.

60. Arfviddsson, B., H. Zachrisson, A.C. Möller-Loswick, A. Hyltander, R. Sandström, and K. Lundholm. 1991. Effect of systemic hyperinsulinemia on amino acid flux across human legs in postabsorptive state. Am. J. Physiol. 260: E46-E52.

61. Heslin, M.J.E., E. Newman, R.F. Wolf, and P.W.T. Pisters. 1992. Effect of hyperinsulinemia on whole body and skeletal muscle leucine carbon kinetics in humans. Am. J. Physiol. 262:E911-E918.

62. Munro, H.N., and A. Fleck. 1969. Analysis of tissues and body fluids for nitrogenous constituents. In Mammalian Protein Metabolism. H.N. Munro, editor. Academic Press, New York. 424-508.

63. Martin, A.F., M. Rabinowitz, R. Blough, G. Prior, and R. Zak. 1977. Measurement of half life of cardiac myosin heavy chain with leucyl-tRNA used as a precursor pool. J. Biol. Chem. 252:3422-3429.

64. Tourian, A., A.J. Goddart, and T.T. Puck. 1969. Phenylalanine hydroxylase activity in mammalian cells. J. Cell. Physiol. 73:159-165.

65. Halliday, D., and R.O. McKeran. 1975. Measurement of muscle protein synthetic rate from serial muscle biopsies and total body protein turnover in man by continuous intravenous infusion of L- $\left[\alpha-{ }^{15} \mathrm{~N}\right]$ lysine. Clin. Sci. 49:581590

66. Cheng, K.N., P.J. Pacy, F. Dworzak, G.C. Ford, and D. Halliday. 1987. Influence of fasting on leucine and muscle protein metabolism across the human forearm determined using $\mathrm{L}-\left[1-{ }^{13} \mathrm{C},{ }^{15} \mathrm{~N}\right]$ leucine as the tracer. Clin. Sci. 73 : 241-246. 